Revista Signum, 2011, vol. 12, n. 1.

\title{
A HISTÓRIA EM TRAJES DE BROCADO. FORMA, TEMPO E PROCESSO EM JOHAN HUIZINGA E HERBERT GRUNDMANN.
}

HISTORY DRESSED IN BROCADE: FORM, TIME AND PROCESS IN JOHAN HUIZINGA AND HERBERT GRUNDAMNN

\author{
Eduardo Henrik Aubert ${ }^{1}$ \\ École des Hautes Études en Sciences Sociales - Paris
}

\begin{abstract}
Resumo: Este artigo tem por objetivo realizar uma leitura detalhada das obras $O$ outono da Idade Média, de Johan Huizinga, e Movimentos religiosos na Idade Média, de Herbert Grundmann, a partir de um núcleo de problemas teóricos fundamentais no panorama de crise do historismo em que elas se inserem. A opção por um tratamento conjunto dos dois livros se justifica como um meio de delimitar a diversidade de respostas dadas pela práxis historiográfica aos problemas que então se lhe colocavam.

Abstract: This article aims at providing a close reading of Johan Huizinga's The Autumn of the Middle Ages and Herbert Grundmann's Religious Movements in the Middle Ages as related to a certain number of core theoretical issues that were especially relevant in the context of the crisis of historicism. The decision to treat the two works together is an attempt to better identify the diversity of responses given by historiographical practice to the problems then raised concerning history.

Palavras-Chave: Johan Huizinga, Key-Words: Johan Huizinga, Herbert Herbert Grundmann, crise do histo- Grundmann, crisis of historicism rismo
\end{abstract}

Artigo recebido em: 09/02/2011

Artigo Aprovado em: 28/06/2011

${ }^{1}$ Bolsista CAPES. E-mail: eh.aubert@hotmail.com. 


\section{Forma, Tempo e Processo na Crise do Historismo}

Diante do descrédito do hegelianismo na universidade alemã desde as décadas de 1840 e 1850, abriu-se caminho para a hegemonia plena do historismo na academia. Termo controverso, pois nomeia o fenômeno a posteriori, o historismo pode ser compreendido de maneira ampla como o fenômeno de "historicização fundamental de nosso saber e de nosso pensamento", ${ }^{2}$ definido pela "idéia de que tudo se tornou histórico e de que tudo é mediado pela história."3 A vertente do historismo que ganha corpo a partir de então em meio aos historiadores é de base objetivista, isto é, "a ciência histórica tinha geralmente a pretensão de oferecer um espelho e um reflexo do mundo e da realidade histórica passada." ${ }^{4}$ Relendo a obra de Leopold von Ranke (1795-1886) e despindo-a de seu conteúdo metafísico, guarda-se apenas a idéia de que a tarefa do historiador é a de apagar-se a si mesmo (Selbstauslöschung). Busca-se o conhecimento pela anulação do sujeito. Nessa concepção, que é uma vertente do empirismo, a história se define por uma compreensão da ciência que exclui a dimensão da pesquisa em sentido próprio: o saber não é construído, mas desvelado ou revelado empiricamente. Essa noção de ciência é devedora especialmente do positivismo das ciências da natureza (Naturwissenschaften), uma teoria científica exposta de maneira lapidar pelo médico Rudolf Virchow (1821-1902), entre outros. ${ }^{5}$

Mas o historismo objetivista é, na verdade, uma ideologia científica, calcada em determinados pressupostos. Dois aspectos dessa concepção da história, intimamente imbricados, merecem ser indicados aqui por terem um impacto decisivo na prática historiográfica. Buscando igualar-se ao padrão de ciência das ciências da natureza, a historiografia historista propugnava um modelo explicativo que, por entender que a ciência está baseada em leis abstratas de validade geral, fundamentava-se em uma articulação de causas e efeitos, independentemente de o vetor explicativo ter uma orientação idealista ou materialista. Nos termos de Charles R. Bambach, “o pressuposto positivista [é] o de que a causalidade histórica poderia ser explicada em termos da categoria de causa e efeito, derivada das ciências da natureza, em busca de leis." 60 modelo explicativo do historismo é o da causalidade simples. O segundo aspecto a ser destacado é uma contrapartida dessa concepção, mas ele tem raízes filosóficas mais profundas, que remontam a Descartes em última instância, mas que mais imediatamente se encontram na epistemologia de Kant, que "pressupôs o objeto de investigação científica como algo de estático e dado, algo que está 'aí' para a análise."7 Se é pos-

\footnotetext{
2 TROELTSCH, Ernst. Der Historismus und seine Probleme (1921). Aalen: Scientia, 1961, p. 9.

${ }^{3}$ OEXLE, Otto Gerhard. L'historisme en débat (1996). Paris: Aubier, 2001, p. 7-8.

${ }^{4}$ Idem, ibidem, p. 15.

${ }^{5}$ RIEDEL, Manfred. 19. Jahrhundert: Positivismus, Historismus, Hermeneutik. Leipzig: Reklam, 1985, p. 266.

${ }^{6}$ BAMBACH, Charles R.. Heidegger, Dilthey and the Crisis of Historicism. Ithaca: Cornell University Press, 1995, p. 110.

${ }^{7}$ Idem, p. 168.
} 
sível isolar causa e efeito e se é possível apagar o sujeito e, portanto, delimitar a distinção entre sujeito e objeto, o ser de cada unidade de causa ou efeito não é sujeito a uma transformação de natureza no interior do processo histórico: ele é "permanente em sua estrutura essencial" ${ }^{8}$ Como no modelo biológico da filogênese, a transformação do ser (na temporalidade alargada da espécie) é o resultado (efeito) da ação do ambiente (externalidade produtora da causa). ${ }^{9} \mathrm{O}$ historismo se ocupa de seres no tempo, e não da temporalidade do ser.

Nas últimas décadas do século XIX, esboça-se uma reação a essa tendência por meio da retomada da questão fundamental levantada por Kant na Crítica da Razão Pura: como é possível obter um conhecimento objetivo da realidade? Em consonância com a resposta kantiana, essa reação se faz centrando o problema no papel do sujeito do conhecimento. Para os chamados neo-kantianos de Baden, em torno de Wilhelm Windelband (1848-1915) e Heinrich Rickert (1863-1936), esse sujeito é um sujeito transcendental, trans-histórico, ao qual cabe a tarefa de apreender a realidade a partir de uma definição metodológica que distinga com precisão os objetivos das ciências humanas, ou do espírito (Geisteswissenschaften) e das ciências naturais (Naturwissenschaften), oposição consagrada na fórmula de Windelband, no célebre discurso de 1894, que nomeia as primeiras idiográficas (pois buscam a particularidade dos fenômenos) e as segundas nomotéticas (pois buscam a generalidade dos mesmos). ${ }^{10}$ Não é o objeto em si que diferencia essas ciências, mas o seu objetivo epistemológico. Heinrich Rickert segue na mesma linha, esvaziando a questão ontológica. Para ele, a realidade é um contínuo heterogêneo, distinto da consciência, e cabe à ciência operar seleções para fins de conhecimento, transformando-a seja em um "contínuo homogêneo", procedimento das ciências naturais, seja em um "discreto heterogêneo", procedimento da história. Enfatizando o problema do valor como forma de diferenciar entre singularidade simples e singularidade essencial, Rickert propõe falar em Kulturwissenschaft. A definição axiológica da singularidade essencial por meio de um eixo referencial de valores configura-se, para ele, como o objeto próprio às ciências da cultura.

Coube a Wilhelm Dilthey (1833-1911) direcionar a crítica ao historismo objetivista em outro sentido, substituindo o sujeito transcendental (neo-)kantiano por um sujeito histórico e reabrindo assim o problema ontológico. A consciência diltheyana existe no contexto histórico da vida humana e, por isso, não é possível, como fazem os historistas, adotar, para as ciências do espírito, uma abordagem estritamente empirista, desconectada do sujeito do conhecimento. Isto porque, como já apontava Johann Gustav Droysen (1808-1884), entre o historiador e o mundo histórico, que é um mun-

\footnotetext{
${ }^{8}$ HUIZINGA, Johan. "The task of cultural history" (1929). In: HUIZINGA, Johan. Men and Ideas: History, the Middle Ages, the Renaissance. Princeton: Princeton University Press, 1984, p. 17-76, aqui p. 35.

9 Ibidem.

10 WINDELBAND, Wilhelm. "Rectorial Address, Strasbourg 1894" (1894). History and Theory, 19 (2), 1980, p. 169-185.
} 
do humano, há "uma identidade e uma reciprocidade essenciais."11 O conhecimento histórico é, assim, essencialmente reflexivo. Diante da questão da distinção entre as Geisteswissenschaften e as Naturwissenschaften, Dilthey fornece uma resposta ontológica: o mundo do espírito se dá a conhecer porque ele é o fruto da consciência. Aqui Dilthey se vale de Hegel, apropriando-se da noção de "espírito objetivo", mas retirando-a do contexto da odisséia da mente hegeliana. Para Dilthey, o mundo da natureza sempre permanece externo e inacessível ao homem, pois o homem não o criou, retomando assim o célebre princípio de Giambattista Vico, segundo o qual aqueles que fazem algo o compreendem melhor do que aqueles que não o fazem. ${ }^{12}$ Porém, diz ele, "nós encontramos na língua, no mito e no ritual religioso, nos costumes, na lei e na organização externa da sociedade os produtos do espírito coletivo, em que, nos termos de Hegel, a consciência humana está objetivada e pode assim se submeter à análise."13 Em termos simples, "as ciências humanas têm como realidade compreensiva o espírito objetivo." ${ }^{14}$

Esse ataque frontal ao objetivismo dominante da ciência histórica no século XIX tem por conseqüência uma revisão necessária dos problemas da causalidade e da temporalidade do ser. Na distinção clássica proposta por Dilthey (mas que tem uma larga pré-história), se a processualidade do mundo natural pode se explicar (erklären) na articulação de causas e efeitos, a processualidade do mundo humano só se pode compreender (verstehen) com um princípio fundamental de empatia, e à relação causal se substitui a relação entre a parte e o todo. ${ }^{15}$ Afinal, se o saber é construído (como pesquisa) na empatia entre objeto (que é um sujeito objetivado) e sujeito do conhecimento, o conhecimento histórico se torna necessariamente uma dialética. Paralelamente, na medida em que o historiador se projeta, por empatia, na história tal qual ela se apresenta "quando ainda está em curso de ser decidida,"16 o objeto histórico perde sua dimensão fechada à temporalidade, e a pesquisa histórica abre-se para a problemática do vir-a-ser de seus objetos como tarefa fundamental da investigação. Em certa medida, passa-se de uma filogênese para uma ontogênese do fenômeno histórico..$^{17}$ Nos

${ }^{11}$ DROYSEN, Johann Gustav. Historik. Rekonstruktion der ersten vollständigen Fassung der Vorlesungen (1857), Grundriß der Historik in der ersten handschriftlichen (1857-1858) und in der letzten gedruckten Fassung (1882). Ed. Peter Leyth. Stuttgart: Fromann-Holzboog, 1977, p. 423.

${ }^{12}$ Cf. BERLIN, Isaiah. Vico e Herder (1976). Brasília: UnB, 1982, p. 8.

${ }^{13}$ DILTHEY, Wilhelm. "Einleitung in die Philosophie des Lebens". In: DILTHEY, Wilhelm. Die geistige Welt (Gesammelte Schriften, 5). Ed. Georg Misch. Göttingen: Vandenhoeck \& Ruprecht, 2008, p. 180.

${ }^{14}$ Apud: BAMBACH, Charles R. Heidegger, Dilthey..., op. cit., p. 162, n. 106

${ }^{15}$ Segundo Huizinga ("The task of cultural history", op. cit. p. 39): "Seja como for, conhecer em sentido histórico raramente, talvez nunca, significa indicar uma causalidade estritamente fechada. É sempre uma compreensão de contextos. Como eu argumentei, esse contexto é sempre aberto (...). Em sua variedade e em sua diferença em valor, novas noções adicionadas a um contexto histórico são como novas flores em um buquê: cada uma muda a aparência do todo."

${ }^{16}$ FREYER, Hans. "Diltheysches System der Geisteswissenschaft und das Problem Geschichte und Soziologie". In: Kultur- und Universalgeschichte. Festschrift für Walter Goetz. Leipzig/Berlim, 1927, p. 499.

${ }^{17}$ HUIZINGA, Johan. "The task of cultural history", op. cit. p. 35.

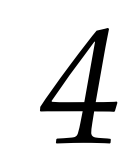


termos de Bambach, "Dilthey enfatizou pacientemente que a temporalidade e a historicidade da vida minam a fixidez de qualquer objeto de conhecimento." 18

É nesse contexto que a noção de forma ganha relevo. Já Windelband opusera forma e conteúdo no núcleo essencial da distinção entre ciências nomotéticas e idiográficas. Segundo ele, “em sua busca por conhecimento da realidade, as ciências empíricas buscam seja o geral na forma da lei da natureza ou o particular na forma da estrutura historicamente definida. Por um lado, elas se preocupam com a forma que permanece invariavelmente constante. Por outro lado, elas se preocupam com o conteúdo único, definido de maneira imanente, do evento real."19 Nessa compreensão, que não está tão distante de Dilthey, a forma nomeia a dimensão acabada (o espírito objetivo) que define o ponto de partida do historiador (na própria empiria das fontes) e reclama a explicação do processo que determinou o seu vir-a-ser (distintamente nomeado conteúdo, fluxo, movimento, etc., conforme o sistema filosófico construído pelos diferentes autores), o espírito em seu contínuo devir, já que ele é pura historicidade. Ela é a instância em que "um fragmento do passado se realizou em seu decurso efetivo." 20 A forma, que funda a possibilidade de apreensão dos diversos objetos, é o ponto de apoio metodológico de uma orientação do conhecimento histórico que temporaliza radicalmente os seus objetos, transformando o problema da ontologia em um problema de temporalidade.

Esse encaminhamento filosófico pode ser considerado como parte de uma "crise do historismo" no sentido de uma "tomada de consciência da própria pesquisa como algo temporal, cultural e científico," ${ }^{21}$ mas, conforme bem apontou George G. Iggers, "o exame dos métodos e dos princípios epistemológicos da história como uma ciência foi fundamentalmente realizado por filósofos" e "foi seguido pelos historiadores com diversos graus de interesse." 22 A epistemologia neo-kantiana estava profundamente distante da prática efetiva da história, e Dilthey nunca conseguiu resolver o problema da objetividade do conhecimento histórico (que ele afirmava, no entanto) diante do estatuto subjetivo e temporal da experiência histórica, possivelmente a razão pela qual ele jamais conseguiu levar a cabo seu projeto de escrever uma Crítica da Razão Histórica, no modelo das críticas kantianas.

Diante desse panorama de crítica do historismo e de crise das ciências históricas, cabe, assim, uma investigação da historiografia que buscou se defrontar com esses problemas, algo que se verifica sobretudo a partir do fim da Primeira Guerra. É o caso de duas obras fundadoras da história cultural do século $X X$ - entendendo-se que cultura não significa para esses autores $u m$ domínio da história, mas $o$ domínio de inscrição da história como Kultur- ou Geisteswissenschaft - O outono da Idade Média (1919), de

\footnotetext{
18 BAMBACH, Charles R. Heidegger, Dilthey..., op. cit. p. 168.

${ }^{19}$ WINDELBAND, Wilhelm. "Rectorial Address...", op. cit. p. 175.

${ }^{20}$ HUIZINGA, Johan. "The task of cultural history", op. cit. p. 57.

${ }^{21}$ BAMBACH, Charles R. Heidegger, Dilthey... op. cit. p. 124.

22 IGGERS, George G. The German Conception of History: the National Tradition of Historical Thought from Herder to the Present (1968). Middletown: Wesleyan University Press, 1983, p. 130.
} 
Johan Huizinga (1872-1945), e Movimentos religiosos na Idade Média (1935), de Herbert Grundmann (1902-1970), ambos clássicos incontestáveis da historiografia medieval com uma larga posteridade na crítica. Retomá-los hoje permite rever o problema espinhoso, porém central, da forma na crítica ao historismo objetivista, resgatando - inclusive para a prática historiográfica de hoje - a dimensão visceralmente histórica que é a do vir-a-ser de tudo aquilo que é.

\section{O Outono da Idade Média (1919) ${ }^{23}$}

O outono da Idade Média: estudo sobre as formas de vida e de pensamento dos séculos XIV e XV na França e nos Países Baixos [Herfsttij der Middeleeuwen: Studie over levensen gedachtenvormen der veertiende en vijftiende eeuw in Frankrijken en de Nederlanden], primeira grande monografia do historiador holandês Johan Huizinga, tem uma história textual complexa, e ainda não existe uma edição crítica que permita comparar a evolução da obra ao longo de suas sucessivas revisões. Sua primeira edição remonta a 1919, mas a obra foi revista já na segunda edição, de 1921, assim como nas traduções realizadas na década de 1920, primeiramente para o alemão (1924) e o inglês (1924), e então para o sueco (1927), revisões incorporadas e aprofundadas nas edições holandesas sucessivas, de 1928 (terceira edição), de 1935 (quarta) e de 1940 (quinta). Como se tornou a edição de referência, é esta última que será analisada aqui. $^{24}$

Se a realização de múltiplas edições e a tradução para diversas línguas (a que se somam o espanhol e o francês na década de 1930) são demonstração evidente do sucesso da obra, sua recepção não foi, contudo, unívoca, e não faltaram críticas misturadas aos elogios, um percurso que não cabe traçar aqui por já ter sido bastante bem mapeado. ${ }^{25}$ Baste dizer que, mesmo entre os círculos bastante receptivos, como o dos primeiros Annales na França, O outono da Idade Média permaneceu um livro elusivo. Apesar de saudá-lo em sua resenha da segunda edição alemã e de considerá-lo item

\footnotetext{
${ }^{23}$ Esta seção é retomada de um artigo a ser publicado na Revista USP. Sou grato ao editor da Revista USP, Francisco Costa, por permitir que esta seção apareça aqui em seu contexto original.

${ }^{24}$ Valemo-nos da recente tradução publicada pela CosacNaify, que, além de um amplo dossiê de textos complementares e farto material iconográfico, é a primeira tradução para o português diretamente do original holandês: O outono da Idade Média. Estudo sobre as formas de vida e de pensamento dos séculos XIV e XV na França e nos Países Baixos. Trad. Francis Petra Janssen. São Paulo: CosacNaify, 2010. A tradução foi sistematicamente cotejada com o original holandês e emendada quando necessário: Herfsttij der Middeleeuwen: Studie over levens- en gedachtenvormen der veertiende en vijftiende eeuw in Frankrijken en de Nederlanden. Ed. L. Brummel. Haarlem: Tjeenk Willink \& Zoon, 1949 (Verzamelde werken, Deel 3). As referências seguem os números de página da edição brasileira e foram inseridas no corpo do texto, entre parênteses, precedidas da abreviação OIM.

${ }^{25}$ Para uma história das edições e traduções, cf. PETERS, Walter e SIMONS, Walter P. "The Old Huizinga and the New Middle Ages". Speculum, 74 (3), 1999, p. 587-620. Para uma avaliação das primeiras fases da recepção, cf. STRUPP, Christoph. Johan Huizinga. Geschichtswissenschaft als Kulturgeschichte. Göttingen: Vandenhoeck \& Ruprecht, 2000.
} 
indispensável em uma biblioteca acadêmica, ${ }^{26}$ Bloch taxou o livro claramente como "um estudo de psicologia histórica, psicologia coletiva, claro", ${ }^{27}$ uma leitura que abre as portas para a retomada do livro no bojo da elaboração e da problemática da história das mentalidades já na década de $1970 .{ }^{28} \mathrm{~A}$ essa caracterização problemática ${ }^{29}$ se soma a crítica, bastante difundida a partir da década de 1930, de que o livro conferiria pouca importância à história social. Esse ponto fora já levantado por Marc Bloch quando ele define uma "lacuna realmente grave" no método de Huizinga: "trata-se sempre da sociedade do tempo como se ela fosse uniforme, ou quase; pode-se, contudo, conceber uma psicologia coletiva que não faça qualquer diferença entre as classes?". ${ }^{30}$

Mas a recepção da obra foi sem dúvida em grande parte determinada pelo interesse de leitores que nem sempre buscaram penetrar na compreensão profunda de uma obra bastante difícil. Para bem delimitar o objeto e a teia argumentativa da obra, parece, assim, mais profícuo mergulhar na leitura do livro, tarefa algo dificultada pela abordagem de Huizinga, pouco afeita à exposição pormenorizada de seus conceitos fundamentais. Na mais explícita formulação a respeito de seu objeto e de seu método de trabalho em O outono da Idade Média, no prefácio à primeira edição, Huizinga escreve, retomando a expressão do subtítulo do livro "formas de vida e de pensamento": "As formas de vida e de pensamento foram as evidências usadas aqui. Aproximar-se do conteúdo essencial que repousa na forma (den wezenlijken inhoud te benaderen, die in die vormen heeft gerust): não será sempre essa a tarefa da pesquisa histórica?" (OIM, 7, tradução modificada) O que Huizinga quer dizer por "formas de vida e de pensamento", assim como por "conteúdo essencial", será sugerido no momento oportuno, mas por ora cabe marcar que esse projeto tem uma dimensão fundamental no seio das Geisteswissenschaften, na medida em que separa nitidamente a história da sociologia tal qual concebida por Georg Simmel (1858-1918), que, na distinção entre forma e conteúdo (da interação social), entendia delimitar a especificidade da sociologia reservadolhe o estudo apenas da forma:

\footnotetext{
${ }^{26}$ Escrevendo a Lucien Febvre de Montpellier, em 9 de outubro de 1942, Bloch lhe diz: "Ocorreu-me a idéia de olhar se havia o Huizinga na biblioteca. Ninguém jamais o comprou. Pobres estudantes!", em BLOCH, Marc e FEBVRE, Lucien. Correspondance. Tome troisième (1938-1943). Ed. Bertrand Müller. Paris : Fayard, 2003, p. 218.

${ }_{27}$ BLOCH, Marc. Resenha em Bulletin de la Faculté des Lettres de Strasbourg, 1, 1928-29, p. 33-35, aqui p. 33.

${ }^{28}$ Contexto em que sai uma nova impressão da tradução francesa, com novo título e com uma entrevista-prefácio de Jacques Le Goff: L'Automne du Moyen Âge. Paris: Payot, 1975. A entrevista foi traduzida para o português na edição da CosacNaify: "Entrevista de Jacques Le Goff a Claude Mettra". O outono da Idade Média, op. cit. p. 588-597.

${ }^{29}$ Segundo Huizinga ("The task of cultural history", op. cit., p. 56): "Se, ao invés de uma compreensão psicológica de pessoas específicas, nós adotarmos uma compreensão da alma das massas - algum tipo de psicologia social - o resultado será uma compreensão histórica menos verdadeira. Imagine que é possível descrever a psicologia social dos habitantes da Inglaterra no século XII. Na verdade, tal psicologia me parece não apenas impossível de se conhecer, mas também impossível de se conceber."

${ }^{30} \mathrm{BLOCH}$, Marc. Resenha em Bulletin de la Faculté des Lettres de Strasbourg, op. cit. p. 35.
} 
Tudo o que os indivíduos, o lugar imediatamente concreto de toda realidade histórica, contêm como pulsões, interesses, objetivos, tendências, estados e movimentos psíquicos, podendo engendrar um efeito sobre os outros ou receber um efeito que provém dos outros - eis o que eu defino como o conteúdo (Inhalt), de certo modo como a matéria-prima da socialização (die Materie der Vergesellschaftung). Essas matérias, que preenchem a vida, essas motivações que a animam, não são ainda nelas mesmas e por elas mesmas uma existência social. Em seu dado imediato e em seu sentido puro, a fome ou o amor, o trabalho ou o sentimento religioso, a técnica ou as funções e os produtos da vida intelectual não representam ainda a socialização; ao contrário, eles apenas a constituem quando eles modelam, a partir da coexistência dos indivíduos isolados, certas formas de coletividade e de comunidade (Formen des Miteinander und Füreinander) que se associam ao conceito geral de ação recíproca. A socialização é, portanto, a forma (Form), que pode se realizar de maneiras incontáveis e diversas, em que os indivíduos constituem uma unidade fundamentada sobre esses interesses - materiais ou ideais, momentâneos ou duráveis, conscientes ou inconscientes, agindo como causas motrizes ou aspirações teleológicas - e no interior da qual esses interesses se realizam. ${ }^{31}$

Na construção simmeliana, ao mesmo tempo em que se reconhece a especificidade das Geisteswissenschaften, tal distinção e o centramento do problema da sociologia na forma da interação social permite limitar o campo de observação a uma parcela do fenômeno humano mais facilmente sondável com as metodologias científicas próprias às Naturwissenschaften, pois que a subjetividade, mesmo que existente e fundadora, não é objeto de sua ciência. Que é na especificidade das Geisteswissenschaften que Huizinga localiza o seu trabalho fica evidente em uma carta inédita de 1922, endereçada a A. J. Derkinderen, em que o autor destrincha o título de seu livro e glosa a fórmula sucinta "aproximar-se do conteúdo essencial que repousa na forma" por meio da própria noção de Geist (geest em holandês):

Mas eu nomeei propositalmente a minha obra: Estudo sobre as formas de vida e de pensamento, e nada mais do que isso... Veja, a história da cultura, como eu a pratico e tal como você a compreende, são muito distintas em propósito e método e não podem ser harmonizadas. Eu leio e observo os produtos do espírito (geesteproducten) e me pergunto: eles surgiram a partir de que espírito (uit welken geest zijn ze ontstaan)? E eu procuro delinear esse espírito, adivinhando, especulando, deixando aqui uma página na sombra, sugerindo ali todo um mundo com um traço. ${ }^{32}$

\footnotetext{
${ }^{31}$ SIMMEL, Georg. Soziologie: Untersuchungen über die Formen der Vergesellschaftung. Frankfurt am Main: Suhrkamp, 1992, p. 18-19

${ }^{32}$ Apud: STRUPP, Christoph Strupp. Johan Huizinga, op. cit. p. 148.
} 
Em vez de "conteúdo essencial" e "forma", encontramos aqui os termos "espírito" e "produtos do espírito", noções interessantes que sugerem ao mesmo tempo uma pertença da obra no seio das Geisteswissenschaften (englobando o "espírito" no escopo de sua problemática imediata e distanciando-se destarte da sociologia simmeliana na prática, se não em princípio) e uma articulação lógica (do espírito aos seus produtos) que levanta o problema da causalidade, ou ao menos de uma processualidade direcionada. Essa glosa sugere igualmente uma afinidade fundamental com o problema diltheyano do "espírito objetivo", conteúdo em fluxo que produz objetivações ou formas de si mesmo. Esses são os pontos fundamentais que caberá investigar concretamente na leitura da obra e a que nos dedicaremos na seqüência como modo de abordar o problema da forma na obra: o plano ou domínio ontológico em que se situa o seu objeto e a lógica explicativa da processualidade aí inscrita.

Uma advertência antes de prosseguir. A substituição de "conteúdo essencial" por "espírito" na carta a Derkinderen é também sintomática de um tateamento lexical, senão conceitual, isto é, de uma definição de objeto que é sutil e complexa em sua relação com as palavras que a nomeiam. Afinal, o que poderia ser facilmente identificável aqui como uma posição idealista assume contornos inesperados conforme Huizinga retrabalha na prática historiográfica concreta a noção de conteúdo - e, por conseqüência, de espírito, se entendermos as noções como associadas, seguindo a exposição da carta - ao ponto de o historiador poder caracterizar todo o empreendimento do livro como um "marxismo alargado" (uitgebreid marxisme), em uma nota manuscrita de seu próprio punho. ${ }^{33} \mathrm{Na}$ busca de entender o trabalho teórico de Huizinga no que respeita ao domínio de seu objeto e à lógica explicativa de sua processualidade, a leitura da obra, acompanhando a prática do historiador que "deixa uma página na sombra e sugere um mundo com um traço", só pode se fazer de modo extremamente sutil, uma vez que a escrita de Huizinga, embora visceralmente teórica, é bastante avessa à delimitação conceitual.

\section{a) Planos Ontológicos}

Ainda que O outono da Idade Média não seja um livro conceitual, na medida em que não se detém na definição de conceitos nem como condição nem como objetivo fundamental ("uma definição não precisa entrar em detalhes", diz ele em um artigo sobre o conceito de história), ${ }^{34}$ há um núcleo fundamental de noções elementares cujas delimitação e articulação constituem o arcabouço do argumento da obra. Essas noções de base aludem a distintos planos ontológicos, isto é, elas correspondem a uma partilha da totalidade do mundo em esferas separadas que permitem, por meio da análise e da síntese efetuadas pelo historiador, buscar a compreensão do conjunto. Parece-nos

\footnotetext{
${ }^{33}$ Apud: STRUPP, Christoph. Johan Huizinga, op. cit. p. 143, n. 90.

${ }^{34}$ HUIZINGA, Johan Huizinga. "En torno a la definición del concepto de historia". In: HUIZINGA, Johan. El concepto de la historia y otros ensayos. México: Fondo de Cultura Económica, 1980, p. 85-97, aqui p. 87.
} 
possível identificar, a princípio, quatro desses planos na narrativa de Huizinga: (1) a "realidade"; (2) o "sentimento"; (3) a "idéia"; e (4) a "forma". Buscaremos, neste momento, delimitar o campo referente a cada uma dessas noções para, em seguida, discutir como elas se articulam umas com as outras e, assim, abordar o problema da processualidade.

A "realidade" (werkelijkheid), ou "vida" (leven) simplesmente, é, na pena de Huizinga, o mundo social objetivo, entendido como plano independente de sua percepção ou apreensão subjetiva por parte dos agentes históricos. É o plano da imanência da objetividade. Para além de "realidade" (OIM, 57, 107, etc.) ou "vida" (OIM, 197, 293, etc.), Huizinga nomeia esse plano de variados modos, "os acontecimentos da vida" (OIM, 60), "vida social" (OIM, 323), "vida comum" (OIM, 375). Ele enfatiza o seu caráter imanente, por exemplo, pela composição dos dois termos na expressão "vida real" (OIM, 199, 432) ou ainda por sua caracterização como "dura" ou "crua", como um domínio que se apresenta para os agentes sem qualquer mediação que o abrande : "dura realidade" (OIM, 56); realidade "violenta, dura e cruel" (OIM, 119), "dura, cruel e falsa" (OIM, 124), ou ainda "amargamente crua" (OIM, 179). A ausência de mediação subjetiva - que é também o plano de inteligibilidade do mundo cru da objetividade imanente - se apresenta nos seguintes termos, quando, falando sobre a guerra e a política, Huizinga diz que elas eram "na realidade... extremamente informes e incoerentes" (OIM, 99).

O "sentimento" (gevoel), ou "emoção" (aandoening) constituem, para Huizinga, o plano mais elementar e mais imediato da subjetividade não-processada. Em contraposição à imanência da objetividade na "realidade", poderíamos falar aqui em um plano de imanência da subjetividade. Sugerindo uma profundidade auto-centrada, Huizinga fala em "sentimento profundo" (OIM, 18) de maneira geral ou em "arrependimento contrito" (OIM, 18), por exemplo, de maneira específica. A qualificação de "emoções vivas" (OIM, 243) sublinha uma força própria a esse domínio. As noções de espontaneidade e pureza nas manifestações emocionais - "manifestações espontâneas de ternura" (OIM, 65), "manifestação pura de afeto" (OIM, 66) - assim como falar em "expressão espasmódica... passional, intensa, mas altamente transitória" (OIM, 312) sugerem a mesma independência desse plano ontológico. O lócus irredutível em que repousa o subjetivo chega a ser nomeado: a "sede de vingança" deve ter "raízes fundas no espírito (geest)" (OIM, 30). A introdução desse domínio no conjunto de sua obra ecoa, na própria prática historiográfica, o princípio fundamental de empatia que, em consonância com a posição diltheyana, caracteriza a práxis das ciências do espírito em contraposição às ciências da natureza. É assim que, falando da obra literária de Boucicaut, Huizinga tece um comentário teórico de importância capital para sua prática em geral: "Mas seja lá qual for o significado que teve toda essa obra, de valor inferior como literatura ou arte, como enfeite da vida, como expressão de sentimentos, somente nos daremos conta disso ao insuflarmos nela novamente a própria paixão autêntica (de levende passie zelf)." (OIM, 121) 
Mas nem tudo é pura imanência no mundo concebido por Huizinga, e mesmo longe disso. Ao distinguir, no campo mesmo da subjetividade, uma esfera que nomeia "idéia" (idee), "conceito" (begrip), ou ainda "conteúdo" (inhoud) (um termo que não é unívoco sob sua pena), Huizinga estabelece um domínio para a subjetividade processada ou estruturada. Nem sempre esse domínio aparece de forma claramente separada dos sentimentos, e isso porque, como veremos adiante, é à noção de "forma" que se reserva o contraponto da imanência, mas a noção de "idéia" está presente em Huizinga e faz aparição em determinados pontos da obra. A diferença entre o processamento da "idéia" e a imediatez da "emoção" talvez esteja mais claramente expressa em uma passagem sobre o pensamento simbólico: "O pensamento simbólico proporciona aquela intoxicação, aquela confusão pré-intelectual dos limites de identidade das coisas, aquele abrandamento do pensamento racional que leva a intensidade do sentimento pela vida a seu auge." (OIM, 339). Ou então quando Huizinga fala no misticismo: "A Igreja ficava atenta tão logo as emoções (aandoeningen) do misticismo se transformavam em convicções bem formuladas (geformuleerde overtuigingen) ou passavam a ser aplicadas à vida social." (OIM, 323) É uma noção que aparece de modo especialmente proeminente em meio às discussões sobre as modalidades de pensamento e sobre as modalidades artísticas, em que Huizinga freqüentemente contrapõe idéia (ou conteúdo em sentido estrito) e forma. É assim que ele fala no "perigo de que justamente nessa forma vívida do conceito (in dien levendingen vorm van het begrip) o conteúdo (inhoud) se perca" $(O I M, 398)$, no "sistema de conceitos medievais... construído até o topo; só restava espaço para colori-lo e ornamentá-lo" (OIM, 458), ou ainda na literatura, em que "a forma está à frente do conteúdo" (OIM, 509). Mais adiante, trataremos do problema desse descompasso entre forma e conteúdo. Por ora, basta sinalizar que, assim como a contraposição com a "emoção" ,de um lado, a diferenciação relativamente à "forma", de outro, permite a Huizinga estabelecer a idéia (como conteúdo) como um plano ontológico próprio.

Cabe esboçar aqui uma breve indagação, que, no entanto, apenas poderá ser respondida satisfatoriamente no item seguinte: esse conteúdo (a idéia) é o mesmo conteúdo de que fala Huizinga quando define o trabalho do historiador como "aproximar-se do conteúdo essencial que repousa na forma" (OIM, 7)? A resposta pela afirmativa não é óbvia, pois, dada a dualidade da forma (vida e pensamento), isso implicaria um pressuposto idealista claro que, conforme se verá, não se sustenta facilmente, e, diante da adjetivação "essencial", sugere-se uma imanência que não é a da idéia, pois esta indica já um processamento. Estamos talvez mais próximos aqui da noção de "conteúdo da vida" - que designa a temporalidade de um processo - como formulada por Heinrich Rickert em sua Philosophie des Lebens (1920):

Assim que o fator formal se opõe ao conteúdo, ele também se opõe à vida. Isso vale para toda forma, sem exceção, e portanto também para a forma da vida (Lebensform). Toda vida flui continuamente. A forma, em oposição, significa estabelecimento de limites (Begrenzung), na verdade ela é 
um limite. A vida se encontra em um movimento constante, e a forma representa, em contraste a ela, algo de estático ou rígido. Assim, as formas da vida se deixam pensar apenas em contraste com o fluxo vital contínuo do conteúdo (Lebensflu $\beta$ der Inhalte), e mesmo assim nós não podemos dispensá-las se nós buscamos algum conhecimento a respeito da vida. ${ }^{35}$

Nós retornaremos a esse problema ao fim do item seguinte, uma vez tratada a questão da processualidade em O outono da Idade Média.

O plano que Huizinga constrói em oposição à imanência da objetividade ("realidade") e à imanência da subjetividade ("sentimento") é, por excelência, o da "forma" (vorm), que deve ser compreendida como correspondente a uma secundidade geral da imanência, seja objetiva (a "forma de vida"), seja subjetiva (a "forma de pensamento"). Resultado de um trabalho da imanência - daí seu caráter de domínio segundo - a "forma" constitui para Huizinga a própria essência da cultura (ela permitia que o homem "não se entregasse à barbárie", OIM, 179). A secundidade é reforçada pelo atrelamento da forma a outros domínios que ela "cerca", "envolve", "acompanha", "enquadra", etc. (OIM, 11, 60, 179). Por vezes, a noção aparece na expressão "dar forma (a algo)" (vorm te geven) (OIM, 161, 247) Nesse campo semântico, mantemo-nos próximos da forma rickertiana. A forma como delineamento do subjetivo é claramente descrita quando Huizinga expõe a noção de formalismo: "A noção inerente da realidade transcendental das coisas significa que cada idéia é definida por limites fixos (onwrikbare grenzen), está isolada numa forma plástica, e que essa forma é a dominante." (OIM, 392, grifos do autor) Numa bela imagem, Huizinga fala em idéias que "vestem trajes de brocado" (OIM, 511). Como processamento do objetivo, as formas de vida, ou "formas de viver", são descritas como um "verniz aplicado sobre a vida" (OIM, 86). Falando em geral do processamento da vida em uma forma, Huizinga diz: "Todas essas formas de vida belamente estilizadas, que precisavam elevar a verdade crua a uma esfera de harmonia nobre, eram partes de uma grande arte da vida..." $(O I M, 79)$

De modo bastante simples, poderíamos esboçar uma dupla oposição que, pela combinação de seus elementos, cria quatro planos ontológicos, a primeira sendo entre imanência e transcendência (transcendência compreendida estritamente como processamento ou trabalho da imanência), a segunda entre objetivo e subjetivo. Assim, temos os domínios do objetivo imanente ("realidade"), do subjetivo imanente ("sentimento"), do objetivo transcendente ("forma de vida") e do subjetivo transcendente ("forma de pensamento"). A introdução de um domínio próprio das "idéias" - espécie de passo intermédio entre o subjetivo imanente e o subjetivo transcendente? - lembranos que essa partilha do mundo em domínios ontológicos distintos não tem por objetivo esquartejar a realidade, mas criar, pela análise, a possibilidade de sua compreensão na síntese. É assim que se coloca o problema que apenas de maneira imperfeita se poderia nomear como causalidade.

\footnotetext{
${ }^{35}$ RICKERT, Heinrich. Die Philosophie des Lebens (1920). Capítulo 4 (consultado online no endereço eletrônico http://www.gleichsatz.de/b-u-t/begin/rick22.html)
} 


\title{
b) O Problema da Processualidade
}

Termo pouco satisfatório porque o próprio Huizinga, em seu estudo sobre a cultura holandesa no século XVII, foi eloqüente quanto à dificuldade de se nomear o problema da causa - ecoando assim a impossibilidade de aplicar o modelo explicativo do erklären diltheyano a fenômenos que se conhecem mais por meio do paradigma do verstehen:

\begin{abstract}
Se essa diferença de fato existiu na cultura, ela tem de ter surgido das précondições materiais, sociais e éticas de que essa cultura nasceu. Não passa pela cabeça de ninguém querer explicar essa cultura inteiramente a partir dessas pré-condições. Não se explica jamais qualquer fenômeno histórico como se pode explicar um processo natural. No melhor dos casos, aprende-se até que ponto ele pode ser compreendido como um todo. A natureza íntima de um fenômeno nos escapará em nossas tentativas de fazê-la decorrer de causas sociais, econômicas, políticas ou espirituais. O historiador, no final das contas, não conhece causas, mas apenas pré-condições, a partir dos quais ele pode dar forma a seu conhecimento e construir as suas conclusões. ${ }^{36}$
\end{abstract}

Simultaneamente, em seu artigo de 1915 sobre "Ideais históricos de vida", Huizinga distinguiu, na explicação de seu objeto, entre o problema da "causa fundamental", a ser "deixado de lado", e "fatores na história", perspectiva que prefere adotar. ${ }^{37}$ Diante dessa abordagem, parece melhor falar em processualidade, entendendo por esse termo o movimento direcionado de um plano ontológico a outro, sem lhe atribuir de antemão o peso de necessidade de que a noção de causa reveste tal movimento.

Tanto o plano da "realidade" como o dos "sentimentos" são, uma vez definidos como planos exclusivos de imanência do objetivo e do subjetivo respectivamente, irredutíveis a outros planos e um ao outro. Antes de detalharmos alguns padrões de interação sugeridos em O outono da Idade Média, cabe registrar claramente que não há preeminência ontológica necessária seja do subjetivo seja do objetivo, o que implicaria rever o estatuto de imanência dos referidos planos.

É verdade, porém, que Huizinga pode pender o seu interesse para um ou outro lado, como ele o faz nitidamente em duas obras posteriores de maneira oposta. Assim, em seu ensaio sobre o jogo, Homo Ludens (1938), a ênfase é no subjetivo - já que "reconhecer o jogo é, forçosamente, reconhecer o espírito, pois o jogo, seja qual for sua essência, não é material" 38 - e é do plano subjetivo que a cultura se desenvolve como secundidade - "encontramos o jogo na cultura, como um elemento dado existente an-

\footnotetext{
${ }^{36}$ HUIZINGA, Johan. Holländische Kultur im 17. Jahrhundert (1941). Munique: C. H. Beck, 2007, p. 15.

${ }^{37}$ HUIZINGA, Johan. "Historical Ideals of Life" (1915). In: HUIZINGA, Johan. Men and ideas, op. cit. p. 77-96, aqui p. 79.

${ }^{38}$ HUIZINGA, Johan. Homo Ludens: o jogo como elemento da cultura (1938). São Paulo: Perspectiva, 2000, p. 6 .
} 
tes da própria cultura, acompanhando-a e marcando-a" ${ }^{39}$ De modo distinto, em $A$ cultura holandesa no século XVII (primeira edição alemã de 1932, seguida da segunda edição revista em holandês de 1941), é o plano objetivo que tem preeminência - os dois primeiros capítulos se ocupam dos aspectos econômicos, políticos e sociais - e é ele que assume papel de anterioridade relativamente à cultura - por exemplo, quando diz que "continua a existir uma espécie de homogeneidade da cultura, que também se desenvolveu a partir do âmbito material, e se contrapôs a uma diferenciação bastante acentuada das classes." 40

Em O outono da Idade Média, o esforço de Huizinga se define talvez mais pela insistência em que o plano do subjetivo imanente deve ser levado tão em conta quanto o do objetivo imanente. É assim que, distinguindo ponto de vista ético (do pesquisador) e êmico (dos agentes históricos), sem invalidar nenhum deles, Huizinga afirma: "Ainda assim, a par da pesquisa sobre as causas políticas e econômicas (staatkundige en economische oorzaken), deve-se ter sempre em conta que, para espectadores e protagonistas, a vingança de sangue era o motivo crucial das ações e dos destinos dos príncipes e dos países." (OIM, 29) Ao mesmo tempo em que "ninguém tentaria negar a presença de causas econômicas (economische oorzaken)" (OIM, 30), as causas subjetivas são postas em relevo, por exemplo, ao fazer derivar determinadas fórmulas do âmago da subjetividade, como aquelas que "florescem da luta séria de uma raça raivosa e passional contra a sua própria altivez e cólera." (OIM, 68)

Isso dito, o ponto crucial da processualidade em O outono da Idade Média tem de se localizar no movimento de criação da forma - isto é, no processamento ou transcendência da imanência nessa secundidade que só pode existir como resultado de um processo. Aqui se localiza, por meio da contraposição entre a "realidade dura" e a "forma bela", um dos eixos centrais da narrativa de Huizinga, isto é, como, diante de uma realidade negativa, os agentes históricos criaram um "mundo sonhado (droomwereld)" (OIM, 56), mundo das "formas de vida e de pensamento" que o historiador analisa, processo em que, para retomar os termos do Homo Ludens, "o homem cria um outro mundo, um mundo poético, ao lado do da natureza." ${ }^{41}$ Trata-se do "costume de sempre prolongar a existência das coisas com uma linha imaginária na direção da idéia (een nulplijn naar den kant der idee)." (OIM, 353) É o tema da oposição entre a "realidade" e as "formas" que domina a narrativa: "A tensão entre as formas de vida (levensform) e a realidade (werkelijkheid) é incrivelmente forte: a luz é artificial e ofuscante" (OIM, 57); "A realidade de uma vida cheia de guinadas desaparece atrás da bela imagem do cavaleiro" (OIM, 107); há uma grande "desarmonia entre a forma de vida e a realidade" (OIM, 173).

Mas a oposição por si só é uma constatação a posteriori; ela não indica como se criaram as formas que vieram a se opor à realidade. É aqui que se pode localizar o eixo fundamental de processualidade da narrativa de O outono da Idade Média: à oposi-

\footnotetext{
39 Idem, ibidem.

${ }^{40}$ HUIZINGA, Johan Huizinga. Holländische Kultur..., op. cit. p. 57.

${ }^{41}$ HUIZINGA, Johan. Homo Ludens..., op. cit. p. 7.
} 
ção entre o objetivo imanente e o subjetivo transcendente, antecede e a funda a oposição entre objetivo imanente e subjetivo imanente:

A vida real (werkelijde leven) não era suficientemente bela, mas dura, cruel e falsa; na carreira militar e na corte, havia pouco espaço para sentimentos de coragem em nome do amor, mas a alma está repleta deles (maar de ziel is er vol van), quer-se vivenciá-los e se cria uma vida mais bonita com jogos preciosos. (OIM, 124-125)

Da oposição entre a "vida real" e os "sentimentos" localizados na "alma", advém um produto, a "forma (de vida, no caso)". Em outro ponto, Huizinga propõe que "os acontecimentos da vida e as emoções relativas a eles são enquadrados (geëncadreerd) em formas belas e elevadas" (OIM, 60), sugerindo que as "emoções" responderiam aos "acontecimentos", mas o enraizamento dos sentimentos que agem na criação das formas em uma primariedade irredutível aos "acontecimentos" está bem assentado em formulações como as seguintes: "eram a forma cerimonial (...) eram a estilização de um sentimento profundo sob a forma de um ato social e solene" (OIM, 18); "as manifestações espontâneas de ternura são cuidadosamente formalizadas (geformaliseerd)" (OIM, 65); "sejam quais forem os velhos tabus que possam estar por trás dos costumes do luto, seu valor cultural vivo é que dá forma ao sofrimento, eles o mostram como algo bonito e elevado." (OIM, 76) Em termos simples, poder-se-ia dizer que as "formas" de que se ocupa Huizinga em O outono da Idade Média são o resultado de um embate dialético - potencializado ao extremo no contexto cultural de que se ocupa - entre a "realidade", de um lado, e os "sentimentos", de outro. É possivelmente em razão dessa base processual dialética que se explica que Huizinga tenha concebido seu livro como uma espécie de "marxismo alargado", 42 e Jacques Le Goff foi particularmente feliz quando caracterizou o livro nos seguintes termos:

\footnotetext{
${ }^{42}$ Em artigo de 1915 que aborda o problema dos "ideais históricos de vida", problema central em $O$ outono da Idade Média, Huizinga ensaia já uma referência ao materialismo histórico, de modo a aproximá-lo de sua abordagem: "Eu tenho o direito de olhar para tais conceitos históricos como fatores realmente ativos na história, de falar de seus efeitos como algo autônomo? Eles não são antes meros fenômenos sintomáticos de superfície, as formas insubstanciais de expressão de uma cultura? É inegável que aqui, mais que em qualquer outro lugar, a posição do materialismo histórico aparece como forte. Nada parece mais plausível do que explicar essas fantasias históricas como apenas a roupagem externa que reveste um objetivo econômico (ou político): arabescos de história cultural e nada mais que isso. Sem dúvida, é sempre a direção dos esforços contemporâneos que determina quais lembranças do passado terão o valor de ideais de vida. Não é preciso nem dizer que apenas aquelas imagens históricas em que o presente consegue se enxergar refletido tornam-se idéias ou símbolos. Nessa medida, eles são, ao surgirem, dependentes da situação social ou política contemporânea. Porém, uma vez que eles estão presentes na mente com o valor de uma idéia ou símbolo, a partir desse momento (trata-se de uma concessão que o próprio materialismo histórico já fez há muito tempo) eles continuam independentemente e, como idéias, eles podem influenciar a evolução ulterior de pensamentos e situações." (HUIZINGA Johan. "Historical Ideals of Life", op. cit. p. 78)
}

\section{5}


Huizinga se empenha em situar a imagem e todo o campo imaginário em relação ao que os marxistas chamam de infraestruturas, isto é, o aspecto econômico. Para os marxistas tradicionais, o mundo das representações pertence às superestruturas. Ora, o que Huizinga mostrou - e os marxistas começam a elaborar essa inversão - é que as representações pertencem, em parte, às infraestruturas. Hoje, quem nos confirma essa intuição de Huizinga não são os historiadores, e sim os etnólogos - como, por exemplo, Maurice Godelier -, que descobrem nas sociedades arcaicas um pensamento simbólico e representações tão profundamente inscritas no desenvolvimento humano, que acabam por defini-las como infraestruturas. ${ }^{43}$

Diante dessa leitura, como devemos compreender as formulações de Huizinga de que sua tarefa consiste em "captar o conteúdo essencial que repousa na forma" ou em observar os "produtos do espírito" e determinar "a partir de que espírito eles surgiram"? Ao invés de dialética, tais expressões não sugerem antes uma preeminência do subjetivo imanente? Parece-nos que tal postura se explique antes por um tom polêmico - o de demarcar uma perspectiva historiográfica contrária às explicações em que a redução ao mundo objetivo dá conta do conjunto da processualidade:

...os motivos políticos e econômicos (economisch-politieke oorzaken) não explicam exaustivamente a luta entre partidos. As oposições econômicas não são mais que construções esquemáticas impossíveis de deduzir dos documentos, nem com a melhor das intenções. (OIM, 30)

O livro seria, assim, em larga medida, um manifesto contra a redução da processualidade ao objetivo imanente. E isso porque a ação do subjetivo imanente (o "espírito") na criação das "formas" é imprescindível, na medida em que, na inexistência de um componente de negação da "realidade", não haveria construção desse "mundo poético" que é o das formas de vida e de pensamento.

No próprio Dilthey, encontramos uma possibilidade de entender o "espírito objetivo" de forma dialética, não como objetivação do espírito hegeliano, mas da Erlebnis (experiência). No comentário de Martin Jay:

Para Dilthey, a experiência (Erlebnis) era um conceito relacional, que implicava algo para além da imanência e imediatez absolutas. Mesmo se, por vezes, ele parecia endossar a posição de que o conhecimento imediato e interior era anterior ao seu reflexo objetivado, ele sempre insistiu na idéia de que a experiência significava um encontro com algo para além da interioridade do sujeito. ${ }^{44}$

\footnotetext{
${ }^{43}$ LE GOFF, Jacques. "Entrevista de Jacques Le Goff a Claude Mettra", op. cit. p. 590-591.

${ }^{44}$ JAY, Martin. Songs of Experience. Modern American and European Variations on a Universal Theme. Berkeley/Los Angeles/Londres: University of California Press, 2005, p. 227.
} 
Nesse contexto, "essas objetivações delimitadas e fixadas [que constituem o "espírito objetivo"] continham um resíduo das intenções teleológicas de seus autores e, como tais, constituíam o que Dilthey chamava de Ausdruck - normalmente traduzido como expressão, mas às vezes também como objetivação - de seu Erlebnis." ${ }^{45}$

Assim, se invertemos a pergunta e nos perguntamos se, para Huizinga, as formas são concebíveis na ausência do objetivo imanente, impõe-se a negativa, uma vez que as formas não só se constroem negando-o (e, portanto, pressupondo-o), como elas o negam por meio de materiais advindos da realidade, caso dos códigos de conduta da cavalaria, por exemplo, que são retransformados pela ação do espírito, mas não inventados ex nihilo por ele. É assim que Huizinga generaliza dizendo que "toda cultura almeja tornar real um mundo sonhado no interior do [mundo] real mediante a recriação das formas sociais (tot zekere hoogte streeft iedere cultuur naar de verwezenlijking van een droomwereld binnen de werkelijke, door het herscheppen van de vormen der samenliving)." (OIM, 56, tradução modificada) Com o risco de simplificação que se corre em formulações compactas, poder-se-ia sugerir que, para Huizinga, o espírito não cria, ele recria, mas que é esse processo de recriação que lhe interessa. Sem a ação recíproca dialética - entre objetivo e subjetivo, não há processo de criação formal, e o relevo que ganha a noção de "espírito" (ou "conteúdo essencial") na exposição de Huizinga só se pode compreender como destaque da antítese em um processo visceralmente dialético.

Se há uma oposição dialética de base - entre imanência do objetivo e imanência do subjetivo - que engatilha uma processualidade em O outono da Idade Média, há uma outra oposição dialética, que se poderia nomear histórica, pois que identificada por Huizinga ao contexto específico da França e dos Países Baixos dos séculos XIV e XV, e que se desenvolve entre o plano de transcendência constituído (a forma) e os planos de imanência. A decorrência do tema essencial de oposição entre a vida dura e o anseio por uma vida bela que cria formas estetizadas é o contra-tema do livro, a idéia de um formalismo preponderante, com formas que se fossilizam, ou "ossificam" (OIM, 243) - "a forma às vezes é tão preponderante que o objetivo se perde completamente" $(O I M, 63)$. No final do período coberto pelo livro, "todo o aparato de fantasia cavaleiresca não era mais preenchido por uma vida autêntica (niet meer van echt leven vervuld)," de modo que se perde o poder criativo da dialética de base, e se assiste ao "desmoronamento interno da forma de vida" (OIM, 432).

As formas fossilizadas potencializam o seu efeito ativo sobre os planos ontológicos de base que lhe deram nascimento. Seu caráter ativo (uma retro-processualidade da processualidade de base) faz parte da própria definição das formas. Afinal, por mais que a forma possa ser vista como simples "verniz aplicado sobre a vida" (OIM, 86) ou motivo de riso para uma "aristocracia cansada" que "ri de seu próprio ideal" (OIM, 147), por definição, as formas de vida, resultantes da "ânsia pela concretização do sonho de beleza nas formas da própria sociedade" (OIM, 57), aplicam-se aos "sen-

${ }^{45}$ Idem, p. 228. 
timentos" e à "realidade", moldando-os por sua vez. "A vida era definida por formas vigorosas" (OIM, 415). O mesmo vale para os sentimentos, quando, por exemplo, vêse que "a sensação de superioridade é alimentada continuamente no pensamento feudal e hierárquico por formas vívidas" (OIM, 38). As formas, nascidas da "vida" e das "emoções", dão forma, por sua vez, a eles.

Se essa dialética está inscrita na própria noção de forma - pois que a forma é transcendência que dá forma à imanência - Huizinga desfila o problema concretamente ao longo de toda a obra, em um vaivém contínuo, da vida à forma e à vida de novo ("As formas de vida são recriadas em formas artísticas. Mas não apenas nas obras de arte em si se expressa o sonho de uma vida bela, pois ela quer enobrecer a própria vida com beleza e preencher a sociedade com jogos e formas." OIM, 57), ou do sentimento à forma e então à vida ("Sem dúvida não é só na literatura e nas belas artes que o anseio pelo amor encontra a sua forma, a sua estilização. (...) nisso a vida imita a literatura, mas esta, em fim de contas, acaba aprendendo tudo na vida.", OIM, 115-116). Em uma apropriação da noção de vida em uma expressão que parece bastante apta a descrever esse movimento dialético, Huizinga fala em "jogo da vida" (levensspel), diferenciando-o por meio de uma metáfora espacial do embate de base entre a "realidade" (werkelijkheid) e o "ideal" (ideaal): "a realidade é violenta, dura e cruel; ela é reduzida ao sonho belo do ideal cavaleiresco e, acima dele, constrói-se o jogo da vida." (OIM, 119)

$\mathrm{Na}$ argumentação do livro, e no tocante ao problema crucial da passagem da Idade Média ao Renascimento, essa instância dialética assume papel central. A fossilização da forma cria um "descompasso" com a "realidade", mas esse "descompasso do século XV significa a passagem para um novo espírito" (OIM, 509), e aqui, no processo de transformação histórica, cabe preeminência à forma, uma vez que "o novo chega como forma exterior antes de realmente se tornar um novo espírito (als uiterlijke vorm, eer het waarlijk nieuwe geest wordt)" (OIM, 554). Nesse sentido, pode-se dizer que tema e contra-tema de O outono da Idade Média desenvolvem processualidades de base dialética que fazem interagir subjetivo e objetivo, assim como imanência e transcendência. Huizinga retrabalha assim o problema da causalidade de forma bastante concreta, demonstrando no bojo da própria narrativa histórica que a negação da causalidade não é uma negação da processualidade, mas um modo de dar conta de múltiplas processualidades, ao mesmo tempo essenciais, pois que independentes da história, e conjunturais, uma vez que estão intimamente atreladas a situações específicas.

\section{Movimentos Religiosos na Idade Média (1935)}

O livro Religiöse Bewegungen im Mittelalter [Movimentos religiosos na Idade Média], publicado originalmente em 1935, a partir de uma tese de habilitação defen-

\section{8}


dida em 1933 na Universidade de Leipzig, é hoje tido por um clássico. ${ }^{46}$ Diferentemente, contudo, de O outono da Idade Média, cultuado desde a sua publicação, a transformação do livro de Grundmann em clássico data da segunda metade do século XX. Um marco fundamental nessa revalorização é a reedição do livro, supervisionada pelo próprio Grundmann, em 1961. ${ }^{47}$ Nesse momento, a demanda por Religiöse Bewegungen já era grande e, de certa forma, pode-se dizer que se manteve bastante intensa até os dias atuais. Escrevendo em 1986, John van Engen era explícito a respeito da posição que Grundmann tinha assumido na segunda metade do século XX: "[Movimentos religiosos na Idade Média] se tornou o fundamento para o estudo da vida religiosa medieval". ${ }^{48}$ Em 1995, era publicada a tradução do livro para o inglês ${ }^{49}$ (havia uma tradução para o italiano datada de 1974), ${ }^{50}$ e uma importante publicação de 2000 definia a obra como "pavimentadora" dos caminhos trilhados a partir da década de 1960, caminho em que esse livro se incluía. ${ }^{51}$

Alguns apontamentos sobre a gestação da obra podem ajudar a introduzir a problemática. A gênese de Movimentos religiosos na Idade Média aparece como uma decorrência clara da linha de investigação iniciada por Grundmann com seu primeiro trabalho acadêmico, o doutorado sobre o místico calabrês Joaquim de Fiore (c. 11321202). Já no princípio desse trabalho, Grundmann confessa que "os estudos sobre o pensamento e sobre as idéias do abade Joaquim de Fiore são o resultado de pesquisas sobre os movimentos espiritualistas dos séculos XIII e XIV."52 Grundmann simplesmente julga que é preciso partir de um estudo minucioso de Joaquim "como problemática em si para compreender apenas depois quando esses problemas podiam se tornar história e como eles se tornaram." 53 Mesmo assim, o quarto capítulo da obra, sobre Joaquim e os movimentos do século XIII, já começa a explorar essa direção. É assim que surge o julgamento segundo o qual "os problemas e as idéias que nasceram nos círculos universitários, no centro da cultura medieval, logo depois colocam o povo

\footnotetext{
${ }^{46}$ Sobre o percurso profissional e intelectual de Grundmann, cf. BORST, Arno. "Herbert Grundmann". Deutsches Archiv für Erforschung des Mittelalters, 26, 1970, p. 327-353; SCHÖPF, Wolfgang G. "Herbert Grundmann". In: Biographisch-Bibliographisches Kirchenlexikon, XVII. Herzberg: Traugott Bautz, 2000, p. 528-546 (consultado online no endereço eletrônico: http://www.bbkl.de/g/grundmann_h.shtml).

${ }^{47}$ GRUNDMANN, Herbert, Religiöse Bewegungen im Mittelalter (1935). Darmstadt: Wissenschaftliche Buchgesellschaft, 1961. Nossa análise do livro está baseada nesta edição. Não indicaremos as referências em notas de rodapé, mas no corpo do texto, por meio da sigla $R B$, seguida do número de página correspondente à citação.

48 VAN ENGEN, John. "The Christian Middle Ages an an Historiographical Problem". American Historical Review, 91 (3), 1986, p. 519-552, aqui p. 523.

${ }^{49}$ GRUNDMANN, Herbert. Religious Movements in the Middle Ages: the Historical Links between Heresy, the Mendicant Orders, and the Women's Religious Movements in the Twelfth and Thirteenth Century, with the Historical Foundations of German Mysticism. Notre Dame: University of Notre Dame Press, 1995.

${ }^{50}$ GRUNDMANN, Herbert. Movimenti religiosi nel Medioevo. Bolonha: Il Mulino, 1974.

${ }^{51}$ FARMER, Sharon e ROSENWEIN, Barbara (Ed.). Monks and nuns, saints and outcasts: religion in medieval society. Ithaca e Londres: Cornell University Press, 2000, p. 2.

${ }^{52}$ GRUNDMANN, Herbert. Studi su Gioacchino da Fiore (1927). Gênova: Marietti, 1989, p. 5.

${ }^{53}$ Idem, p. 10.
} 
em movimento, pessoas excêntricas com pouca cultura e fanáticos incultos, que se engajam no movimento com um afinco fanático." ${ }^{54}$ Daí surge o princípio de analisar aquela instância que Grundmann chamou "[o lugar] onde vivem as idéias":

E ainda que, no entretempo, as idéias possam ser sepultadas e deformadas, ainda que, em uma atmosfera completamente diferente, elas possam produzir os seus efeitos de modo completamente diverso, ainda que sonhadores religiosos ou agitadores políticos possam ser movidos por elas e ainda que essas singulares expressões humanas possam ser associadas entre si de maneira muito pouco visível e muito confusa - o fim último da história do espírito apenas pode ser o de reconhecer onde, em tudo isso, vivem de fato essas mesmas idéias. ${ }^{55}$

O que sobressai desses extratos é a distinção fundamental entre dois planos: de um lado, as idéias, o pensamento; de outro, o movimento espiritual, o "lugar" das idéias. Distinção que caberá investigar na leitura de Movimentos religiosos na Idade Média. Mas, antes disso, algumas linhas a respeito da recepção do livro são importantes. No processo de classicização da obra, elaborou-se uma avaliação ao mesmo tempo de seu objeto e de sua abordagem. Avaliação polêmica que merece ser reexaminada. $\mathrm{O}$ objeto é compreendido como uma profusão de temas, a tal ponto que Van Engen caracteriza a obra como "uma série de ensaios relacionados." 56 Não se trataria antes de dificuldade (por parte da crítica) em localizar o tema do livro, tratado e encaminhado em cada "ensaio"? A compreensão da abordagem de Grundmann também suscitou dificuldade: para Van Engen, "o que Grundmann ensinou aos historiadores acima de tudo foi levar a sério tanto a centralidade desses movimentos na história medieval quanto a motivação religiosa dos que a eles aderiram a despeito de origens, fossem cátaros ou espirituais livres," ${ }^{57}$ posição consonante com a de Caroline W. Bynum, para quem Grundmann "estava reagindo contra interpretações que enfatizavam causas econômicas e sociais"; 58 para os prefaciadores de Monks and nuns, saints and outcasts, contudo, "o grande avanço de Grundmann foi o de ver relações. Isso ele pode fazer em parte ao olhar para as origens sociais comuns dos que aderiam a grupos heréticos ou mendicantes." 59 Duas avaliações flagrantemente conflitantes, que levantam o problema da reapropriação dessa obra na segunda metade do século $X X$, um problema que não pode-

\footnotetext{
54 Idem, p. 177.

55 Idem, p. 194.

56 VAN ENGEN, John. “The Christian Middle Ages...”, op. cit. p. 524.

57 Idem, p. 523-4.

${ }_{58}$ Caroline W. Bynum. Jesus as Mother: Studies in the Spirituality of the High Middle Ages (1982). Berkeley/Los Angeles/Londres: University of California Press, 1984, p. 13, n. 12.

${ }^{59}$ FARMER, Sharon e ROSENWEIN, Barbara (Ed.), Monks and nuns..., op. cit., p. 2.
} 
mos investigar aqui, mas que mereceria um tratamento detalhado. ${ }^{60}$ Desde já, contudo, parece correto afirmar que Grundmann suscitou ao mesmo tempo muito mais uso concreto e muito menos exegese do que O outono da Idade Média.

Infelizmente, Grundmann era pouco afeito à discussão teórica explícita. Ele não deixou o mesmo legado de escritos teóricos que Huizinga, e não situou explicitamente o seu estudo nos quadros de uma problemática conceitual. Nisso ele seguiu o redirecionamento dado ao Institut für Kultur- und Universalgeschichte por Walter Goetz (18671958), após a partida de Karl Lamprecht (1856-1915), que cautelosamente afastou a abordagem científica altamente teorizante de seu antecessor. ${ }^{61}$ É nesse espírito de práxis historiográfica, com uma atenção particular para a delimitação concreta do objeto, que Grundmann rebate seus críticos no prefácio que escreveu para a reedição de $M o-$ vimentos religiosos em 1961:

Contudo, eu nunca me interessei em fornecer uma visão de conjunto representativa de todos os movimentos religiosos do conjunto da Idade Média, mas antes uma pesquisa sobre conexões específicas (bestimmter Zusammenhänge) entre as criações de novas comunidades, tanto dentro quanto fora da Igreja, que almejavam viver e agir de acordo com os mesmos impulsos (Impulsen) próximos, vindos dos conselhos dos Evangelhos e do exemplo dos apóstolos. ( $R B, 2-3$, grifo do autor)

Os termos dessa definição de objeto são interessantes (conexões, impulsos), mas apenas uma leitura cuidadosa da obra, atenta à delimitação do objeto e ao seu tratamento por parte de Grundmann, permite interpretá-la, na tentativa de extrair dos casos concretos uma perspectiva de abordagem teórica. Há uma afinidade de fundo entre a historiografia de Grundmann e O outono da Idade Média. Em um livro posterior, um original manual sobre as heresias medievais em que Grundmann retoma diversos dos temas de Movimentos religiosos na Idade Média, o autor chega a empregar a mesma

${ }^{60}$ Os conflitos de avaliação não são, evidentemente, gratuitos. Uma avaliação da fortuna crítica da obra está para além de nossos propósitos, mas cabe indicar um traço fundamental nesse resgate de Movimentos religiosos: a articulação da leitura de Grundmann com o desenvolvimento da história social em diversas vertentes. Na Itália e na França, foi o problema da religião popular e seu desdobramento no debate sobre a relação entre níveis de cultura e grupos sociais que norteou a retomada de Grundmann via Rafaello Morghen, Arsenio Frugoni, Cinzio Violante, Raoul Manselli (que escreveu a introdução à tradução de Movimentos religiosos para o italiano), Étienne Delaruelle, Marie-Dominique Chenu, André Vauchez, Jacques Le Goff (que já em 1964 citava Grundmann na bibliografia de sua Civilização do Ocidente medieval) e Jean-Claude Schmitt, entre outros. Na Inglaterra e nos Estados Unidos, um pouco mais tarde, foi o problema da multiplicidade das relações sociais (com o problema do gênero em primeiro plano, junto com uma atenção aos grupos heréticos e a outros setores marginais) e das construções identitárias que levou à leitura de Grundmann via Richard Southern, John B. Freed, John Van Engen, Robert E. Lerner, Robert Ian Moore, Lester K. Little e Carolyne Walter Bynum, entre outros.

${ }^{61}$ Sobre Goetz, cf. GRUNDMANN, Herbert e WAGNER, Fritz. "Walter Goetz". Archiv für Kulturgeschichte, 40, 1958, p. 271-274. Sobre Lamprecht, cf. CHICKERING, Roger Chickering. Karl Lamprecht. A German Academic Life. Atlantic Highlands: Humanities Press, 1993. 
fórmula do subtítulo de O outono da Idade Média: "compreender as formas de pensamento e de vida (Denk- und Lebensformen) da Idade Média a partir das pré-condições e intenções próprias à época." 62 Mas, mesmo se eles se colocam, em larga medida, no mesmo campo de problemas, Grundmann e Huizinga fazem opções distintas de percurso, levando a posições historiográficas diferentes. Nessa leitura, que buscará a especificidade da abordagem de Grundmann em Movimentos religiosos, partiremos dos dois termos que dão nome à obra - "movimentos religiosos" - abordando-os sucessivamente nas duas seções que se seguem. O problema central da forma - e, portanto, da noção de objeto histórico - e o da processualidade estão intimamente imbricados com esses termos. Por meio dessa análise, poderemos voltar, na conclusão, ao problema das soluções historiográficas dadas às principais questões que eram colocadas à prática do historiador pela crítica do historismo objetivista.

\section{a) Do Movimento à Forma}

Grundmann abre seu livro com uma epígrafe retirada de um artigo do filósofo Hans Freyer (1887-1969) sobre Dilthey:63

O historiador restaura a história à situação complexa que prevalecia quando ela ainda estava em curso de ser decidida. Ele a põe no presente uma vez mais, revivendo suas alternativas agudas. No verdadeiro sentido da palavra, ele a faz acontecer de novo, isto é, ele faz com que ela seja novamente decidida. Ele dissolve o conteúdo, o produto, a forma do trabalho completo ou do fato feito, ao mesmo tempo recorrendo à vontade, ao poder vivo da decisão, a partir dos quais esses trabalhos e feitos cresceram. $(R B, 5)$

Prestando momentaneamente atenção apenas à segunda parte da epígrafe, verificamos que se expressa aí uma oposição. De um lado, estão "o conteúdo", "o produto", ou "a forma" do "trabalho completo ou do fato feito". De outro, "a vontade", "o poder vivo da decisão". Além de uma oposição, estabelece-se uma relação de origem: os primeiros nascem dos segundos - "a partir dos quais esses trabalhos e feitos cresceram" - ainda que o trabalho do historiador seja inverso, pois ele parte do "fato feito" para chegar à "vontade." Formulação muito próxima da de Huizinga, que pretende "aproximar-se do conteúdo essencial que repousa na forma."

Mas, como essa preocupação enunciada na epígrafe é concretamente trabalhada por Grundmann? É significativo, a esse respeito, que a primeira frase do livro de Grundmann retome o mesmo tipo de relação lógica: “Todos os movimentos religiosos da Idade Média atingiram realização quer em ordens religiosas, quer em seitas heréti-

\footnotetext{
${ }^{62}$ GRUNDMANN, Herbert. Ketzergeschichte des Mittelalters. Ein Handbuch. Göttingen: Vandenhoeck \& Ruprecht, 1963, p. 2.

${ }^{63}$ FREYER, Hans. “Diltheysches System der Geisteswissenschaft...”, op. cit. p. 499.
} 
cas." $(R B, 5)$. De um lado, o "movimento religioso" - o título da obra de Grundmann , de outro, "ordens religiosas" e "seitas heréticas". Novamente, há uma passagem de um ao outro, os primeiros se realizando nos segundos. É a mesma relação retomada, ainda na introdução, quando Grundmann diz que vai "tentar entender a peculiaridade original, as forças históricas e os objetivos religiosos desses movimentos (die geschichtlichen Kräfte und die religiösen Ziele jener Bewegungen) a partir dos quais formas individuais (einzelnen Gebilde) de ordens religiosas e seitas cresceram" (RB, 8-9). O estudo de Grundmann define-se na relação entre dois termos, uma origem, e um produto, um "movimento" (Bewegung) e uma "forma" (Form, Gestalt, Gestaltung, Gebilde). Nesse sentido, é possível reconhecer, desde já, pela ênfase em dois pólos e pela articulação marcadamente unidirecional entre eles, que essa posição se distingue da de Huizinga.

A distinção e sua modalidade de articulação causal constituem um fundamento definidor da historiografia de Grundmann. Em sua breve contribuição ao colóquio Hérésies et sociétés dans l'Europe pré-industrielle, já em 1962, é a mesma posição que expressa Grundmann, que defende substituir as categorias propostas pelo colóquio heresias eruditas e heresias populares - pela diferença entre "heresias primordiais ou iniciais" e "heresias dos sectários". Os primeiros iniciam uma heresia (que é estritamente do domínio espiritual); os segundos dão-lhe existência na história, no domínio social:

Talvez os historiadores da Igreja e da espiritualidade, do pensamento e da personalidade se interessarão mais pelos heresiarcas iniciais, enquanto a história social preferirá, naturalmente, os aspectos sociais das seitas heréticas ao estudo dos fenômenos propriamente religiosos ou intelectuais das heresias quando elas estão nascendo. ${ }^{64}$

Na discussão, a distinção é retomada de maneira sucinta: "Em suma, é necessário distinguir entre um fenômeno social, o das condições de aparição e de influência das seitas, e a heresia, um fenômeno religioso e intelectual."

Do ponto de vista da delimitação dessa problemática - no interior da mesma temática - Grundmann inspirava-se certamente em parte da produção de Walter Goetz, que dirigiu o Institut fur Kultur- und Universalgeschichte entre 1915 e 1933. Já em 1903, em um estudo sobre "O ideal originário de São Francisco de Assis" - artigo citado por Grundmann como dotado de uma "crítica esclarecedora"66 - destinado a tratar "não apenas da determinação de suas idéias originárias (ursprünglichen Idee), mas também de seu desenvolvimento ulterior (Fortentwicklung)" ${ }^{67}$ - , expondo a polêmica

\footnotetext{
${ }^{64}$ GRUNDMANN, Herbert. "Hérésies savantes et hérésies populaires au Moyen Age". In : LE GOFF, Jacques (Ed.). Hérésies et sociétés dans l'Europe pré-industrielle (11e-18e siècles). Paris/La Haye: Mouton \& Co., 1968 , p. 209-218, aqui p. 213-214.

${ }^{65}$ Idem, p. 218.

${ }^{66}$ GRUNDMANN, Herbert e WAGNER, Fritz. “Walter Goetz", op. cit. p. 583.

${ }^{67}$ GOETZ, Walter. "Die ursprünglichen Ideale des Hl. Franz von Assisi" (1903). In: GOETZ, Walter. Italien im Mittelalter: Ersten Band. Leipzig: Roehler \& Amelang, 1942, p. 125-160, aqui p. 129.
} 
historiográfica e analisando as primeiras fontes de legitimidade incontestada, Goetz estabelece que o movimento franciscano (franziskanischen Bewegung) estava, desde o princípio, direcionado à realização em uma ordem organizada (organisierter Orden), ou forma (Form):

\begin{abstract}
Assim, o testemunho das mais antigas fontes de que dispomos concordam em dizer que o que seria posteriormente a ordem primeira constituía o cerne de todo o movimento franciscano e que, desde o começo e partindo do desígnio do fundador, foi inerente a esse movimento o direcionamento para uma ordem monástica, embora ela não se tornasse imediatamente uma ordem cuidadosamente organizada; o que Francisco queria a exata e literal imitação da vida dos apóstolos, a pobreza perfeita, a entrega à oração, a pregação para o despertar das almas - na Cristandade do século XIII, tudo isso, extensível a um grande número de seguidores, só era pensado como podendo ser realizado na forma de uma ordem (in der Form eines Ordens) ${ }^{68}$
\end{abstract}

Em 1927, Goetz coloca-se no mesmo campo temático, mas passa à problemática mais ampla de "determinar o lugar da religiosidade de São Francisco no interior dessa religiosidade medieval." 69 Goetz discute a lenta penetração do cristianismo até o momento em que, nos séculos XII e XIII, como resultado dos movimentos reformistas desencadeados nos séculos precedentes, nasce uma "religiosidade altamente produtiva" (eine in höchstem Maße produktive Religiosität). ${ }^{70}$ Neste momento, nos termos de Goetz, "a religiosidade se torna conteúdo de vida (Lebensinhalt), e imediatamente começa sua própria busca." ${ }^{71} \mathrm{O}$ que o Lebensinhalt busca é, naturalmente, Lebensform..$^{72}$ Anunciando um dos principais temas grundmannianos, Goetz afirma que tanto os que eram pela Igreja quanto os que eram contra a Igreja partem do mesmo fundo religioso, direcionando-se para a forma: "mas a razão espiritual (der geistige Grund) é, nos dois casos, a mesma: ela é a mesma vontade de realizar a experiência do religioso e de dar-lhe forma (der Wille, selber das Religiöse zu erleben und zu gestalten)" ${ }^{73}$

Grundmann certamente recupera o campo delimitado por Goetz - objeto e problemática - mas ele o faz de modo nitidamente mais bem delimitado. Cabe aqui uma referência ao autor da epígrafe de Movimentos religiosos na Idade Média, o filósofo e sociólogo Hans Freyer, então diretor do Institut für Kultur- und Universalgeschichte, em sucessão a Goetz, pois ele certamente teve um importante impacto na prática de Grundmann. Em sua Teoria do Espírito Objetivo, Freyer entende construir uma filosofia

\footnotetext{
${ }^{68}$ Idem, p. 141-142.

${ }^{69}$ GOETZ, Walter. "Franz von Assisi und die Entwicklung der mittelalterlichen Religiosität". In: GOETZ, Walter, Italien im Mittelalter, op. cit. p. 161-192, aqui p. 162.

${ }^{70}$ Idem, p. 165.

${ }^{71}$ Ibidem.

${ }^{72}$ Expressão usada por Goetz logo antes: Idem, p. 163.

${ }^{73}$ Idem, p. 165-166.
} 
da cultura de base hegeliana, que se ocupa da objetivação do espírito em formas, tentando dar "à filosofia do espírito surgida na época do Romantismo uma viragem realista," na base da qual se encontra um impulso subjetivo, uma "vontade da forma (Willen zu Form)," 74 onde elas buscam se enraizar, um importante aspecto do espírito objetivo freyeriano.

Afinado com essa visão idealista, Grundmann faz coincidir a imanência com o subjetivo e a transcendência (da imanência) com o objetivo. Nesse sentido, ele se alinha nitidamente com uma leitura mais idealista do "espírito objetivo" do que a de Dilthey. Essa guinada freyeriana do conceito estava já dada em 1921, quando Freyer postulou a "realidade espiritual" como nível fundamental e propulsor do espírito objetivo. Para Freyer:

Examinando a arte, a ciência, a religião e a economia como sistemas do espírito objetivo (als Systeme des objektiven Geist betrachtet), põem-se de lado todas as conexões que podem ser encontradas de forma secundária entre mundos separados e incomparáveis; separá-las uma da outra como domínios próprios é bem ao que leva uma tendência de conceptualização. Se, ao contrário, refletirmos a partir da realidade espiritual que sustenta o espírito objetivo (die seelische Wirklichkeit, die das objektive Geist trägt), então aquilo que é heterogêneo é trazido a um denominador comum. Assim se torna importante e compreensível pensar em conjunto a vontade artística, a religiosidade, o ethos da ciência, a disposição econômica no campo da unidade de uma consciência cultural, de um espírito da época. E, assim, nessa síntese, tornam-se primeiramente problemas solúveis as mudanças de sentido e os deslocamentos de acento dos âmbitos culturais em sua relação uns com os outros. ${ }^{75}$

Tem razão, nesse ponto, Wolfgang Schöpf, ao destacar o conteúdo hegeliano do trabalho de Grundmann: "Pode-se seguramente dizer que a filosofia da história hegeliana, em especial, trouxe traços importantes ao trabalho de Grundmann, e isso está mais pronunciado em sua tese sobre Joaquim de Fiore."76 Essas relações só podem ser

${ }^{74}$ ÜNER, Elfride. Soziologie als „Geistige Bewegung“: Hans Freyers System der Soziologie und die "Leipziger Schule“. Weinheim: VCH, 1992, p. 35-36.

${ }^{75}$ FREYER, Hans. Die Bewertung der Wirtschaft im philosophischen Denken des 19. Jahrhunderts. Leipzig: Wilhelm Engelmann, 1921, p. 4.

${ }^{76}$ De fato, em seus Estudos sobre Joaquim de Flore, Grundmann cita Nietzsche, estabelecendo uma conexão com a filosofia hegeliana, nos seguintes termos: "encontrar, no lugar de uma teodicéia, uma cosmodicéia, uma biodicéia; ao invés de uma justificativa do Deus do Além nos confrontos com as carências da realidade, encontrar uma justificativa da realidade divino-humana diante das carências do fazer e desfazer humanos. Naqueles séculos, esse impulso não levou a uma formação permanente, ele se perdeu em fanatismo e fervor (e freqüentemente mesmo em luxúria), ou então, onde ele se elevou a níveis espirituais superiores, ele foi deformado no sentido da ortodoxia." (Studi su Gioacchino..., op. cit. p. 182) Aqui o estudo da filosofia da história parece se coadunar com sua própria prática historiográfica. Além disso, registre-se que Arno Borst cita um estudo inédito de Grundmann sobre Kant e a história (BORST, Arno. “Herbert Grundmann”, op. cit. p. 336).

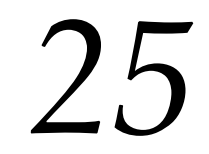


sutis, pois Grundmann não se atém em qualquer ponto à delimitação sistemática de seus conceitos, muito menos a traçar a sua gênese filosófica.

Nessa correlação, o fio que une o que aparentemente é uma "coletânea de ensaios relacionados" se torna mais evidente. Por essa razão, podemos seguir a leitura do livro, capítulo a capítulo, como um desdobramento dessa problemática, um só tema com múltiplas variações. É o que faremos no restante desta seção do texto, uma vez que, conforme indicaremos mais à frente, a repetição da ontogênese do movimento religioso acaba por configurar uma ontologia histórica.

Nos primeiros dois capítulos, trata-se do "movimento religioso no século XII" em termos de seus ideais, "a vida apostólica" e a "pobreza cristã" - de sua subjetividade oposta à Igreja hierárquica institucional que, a partir do século XII, não consegue mais incorporar o movimento religioso - até o seu resultado, o "fato feito" das novas ordens (mendicantes) surgidas no começo do século XIII. Trata-se de uma "consciência (Gesinnung)", que buscou "realizar a Cristandade como um modo de vida religioso (als einer religiösen Lebensform) que dizia respeito imediatamente a cada cristão genuíno individualmente, um comprometimento mais essencial para a salvação do que sua posição no ordo da Igreja ou sua crença nas doutrinas dos Pais da Igreja e seus teólogos" ( $R B, 14$, grifos do autor). Esse movimento não atingiu uma forma até a época de Inocêncio III. Até então, "um teimoso apego à velha forma eclesiástica hierárquica (hierarchischen Form) resultou na exclusão das novas forças religiosas (religiösen Kräfte) da Igreja" $(R B, 65)$. Já Inocêncio III, no começo do século XIII, segundo Grundmann, "se esforçou para acabar com a distância entre o movimento religioso e a Igreja hierárquica ao ceder às demandas de pregadores apostólicos e devotos da pobreza evangélica por um lugar no interior da própria Igreja" $(R B, 71)$. A partir daí, na avaliação de Grundmann, "a hierarquia e o movimento religioso não mais se opunham, mas haviam antes se unido em um novo todo (einem neuen Ganzen)" (RB, 156). A narrativa se suspende aí, e, como Grundmann se explica em nota: "não vou seguir a história da evolução dos franciscanos nem o trabalho de Domingos. Eu acho que já expliquei de forma adequada as precondições para a formação das ordens (die Voraussetzungen dieser Ordensentwicklung)" (RB, 156). Esse primeiro momento da narrativa é fundador, na medida em que é da história dessas precondições, do descompasso entre o subjetivo e o objetivo, que, Grundmann se ocupa. Uma vez o fosso desfeito, Grundmann suspende a narrativa. ${ }^{7}$

Após recuar, no capítulo 3, para traçar as origens sociais de humiliati, valdenses e franciscanos, por razões que exploraremos mais à frente, Grundmann se volta, no capítulo 4, para "as origens do movimento religioso das mulheres". Afinal, segundo Grundmann, Inocêncio III havia tratado do movimento religioso nos países de língua

\footnotetext{
${ }^{77}$ Nesse sentido, parece equivocado afirmar, como o fez van Engen, que Grundmann simpatizasse mais com a não-institucionalização: "De fato, diz van Engen, a institucionalização de um movimento religioso não lhe parecia nem desejável nem possível". (VAN ENGEN, John. "The Christian Middle Ages...", op. cit. p. 524) Ao contrário, Grundmann identifica na Idade Média um desejo da objetivação do movimento religioso, e ele o vê mesmo como positivo, associado que está à "vontade da forma" freyeriana.
}

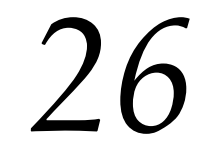


romana e no que respeita especialmente a comunidades masculinas. "Agora, entretanto, comunidades religiosas femininas de uma região germânica e do norte da França, o bispado de Liège, estavam buscando reconhecimento da cúria" $(R B, 171)$. Isto é, uma questão aparentemente secundária se insere aqui na lógica mais geral do trabalho de Grundmann: como as mulheres dessa região ainda não tinham dado "forma" institucional a seu "movimento religioso", Grundmann vai se ocupar delas. Esse movimento compartilhava diversas características com o movimento religioso do século XII, apesar de também guardar diferenças com relação a ele $(R B, 187-188)$. A oposição com a Igreja toma papel de primeiro plano aqui também: "A contradição interna (innere Widerspruch) entre o modo de vida do clero e as demandas do Evangelho foram o primeiro estímulo para o seu desenvolvimento (der erste Anstoß ihrer Entfaltung)" (RB, 197).

Assim como os capítulos 1 e 2 formaram um par, também o 4 encontra seu desdobramento no 5, de acordo com a mesma lógica: trata-se da incorporação do movimento religioso das mulheres nas ordens mendicantes, isto é, sua objetivação como forma. Afinal, "a cúria estava sempre preocupada em estruturar todos os movimentos religiosos nas formas definidas de ordens reguladas (alle religiösen Bewegungen in die festen Formen regulierter Orden einzufügen)" (RB, 200). A narrativa de Grundmann não poderia ser mais clara: "O movimento autônomo (selbständige Bewegung), agressivo das mulheres religiosas, em um grau elevado, tinha se desenvolvido nas formas definidas (festen Formen) de ordens eclesiásticas, apesar de todos os esforços das ordens mendicantes em contrário" $(R B, 311)$. Novamente, o movimento dá origem à forma, ele a implica. Nesse caso, especificamente, Grundmann chama a atenção para um aspecto importante que ilumina boa parte da narrativa subseqüente: "Permanece historicamente significativo que o movimento religioso das mulheres não adquiriu sua forma organizacional (ihre organisatorische Gestaltung) por conta própria, mas por um poder externo, as medidas políticas da cúria e as ordens mendicantes" $(R B, 311-312)$. Assim sendo, conclui Grundmann, o processo não foi pleno, isto é, algumas mulheres ficaram de fora, desenvolvendo seu movimento religioso por conta própria, sob o perigo da heresia, e outras, mesmo no interior de uma "forma", por ela não ser inteiramente compatível com o "movimento", por ela ter vindo de fora e não ter sido o resultado da objetivação da subjetividade, nunca se sentiram plenamente realizadas. Assim sendo, segundo Grundmann, essas mulheres " 'tomaram a via interior', para longe da pobreza evangélica, apostólica, e em direção a uma pobreza interior, espiritual, para longe de uma renúncia externa e em direção a uma paz interior, para longe do movimento de pobreza religiosa e em direção ao Misticismo Alemão" $(R B, 312)$.

A partir daí, Grundmann passa justamente a se dedicar às inadequações entre subjetivo e objetivo, isto é, ao "movimento religioso" naquilo que o define, sua distância (tendencialmente diminuída e ulteriormente eliminada) com relação às formas objetivadas. A objetivação é o fim do "movimento", sua estabilização, em uma definição de forma que se aproxima da noção de Rickert, exposta acima, como limitação que se opõe ao fluxo contínuo da vida. Daí que o capítulo 6 se dedique às beguinas, nome que, desde cerca de 1230, associava-se às "comunidades de mulheres religiosas que

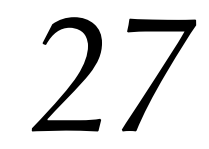


não eram nem conventos regulados, nem pertenciam a ordens" $(R B, 320)$. Caracteristicamente, diz Grundmann, "as beguinas nunca representaram uma forma específica (Sonderform), deliberada, criada de forma planejada, de vida religiosa; elas antes eram o resultado do movimento religioso das mulheres na medida em que ele não encontrou recepção nas novas ordens" $(R B, 320)$. Segundo Grundmann, elas não encontraram nicho no sistema dos estados eclesiásticos ( $R B$, 320-321). Com o tempo, entretanto, elas buscam regulação e reconhecimento, levando enfim a uma distinção:

Enquanto uma parte, sem dúvida de longe a maior, levava uma vida regulada nas beguinagens, freqüentemente com laços com os conventos das ordens mendicantes, ganhando a vida com ofícios manuais, a outra parte dava motivo a reclamações, devido ao fato de as mulheres não manterem clausura e vagarem sem restrição, preferindo esmolas ao trabalho. $(R B$, 344)

É esse segundo tipo de beguinas, por prolongarem a inadequação entre subjetivo e objetivo, que dá o mote para o próximo capítulo, de número 7, sobre "a heresia do 'Livre Espírito' no movimento religioso do século XIII". Grundmann identifica aqui os laços entre as beguinas não-reguladas e a heresia do Livre Espírito, em uma escalada das experiências religiosas" $(R B, 412)$. Não que esse conteúdo estivesse ausente das beguinas reguladas:

A diferença profunda entre as beguinas de Magdeburgo e as heréticas no Ries estava - desconsiderando os poderes de expressão poética e religiosa de Mechthild e sua paixão espiritual - não nesses fundamentos da experiência, que são comuns a todo o movimento religioso feminino, mas na dívida intelectual de suas experiências com relação à doutrina da Igreja. Mechthild havia se encaixado conscientemente na ordem eclesiástica, confiando-se à condução espiritual de seus amigos dominicanos, e ela depois entrou em um convento. As heréticas do Ries, por outro lado, desconfiavam e rejeitavam a condução espiritual de líderes teologicamente treinados, já que tais homens não tinham qualquer entendimento das experiências religiosas que preenchiam suas vidas; elas desdenhavam a vida claustral, já que sua piedade da experiência, que não as ligava a qualquer regra específica, significava infinitamente mais; e todas as disposições da Igreja haviam perdido todo o sentido para elas. $(R B, 418-419)$

O ponto decisivo no movimento religioso feminino do século XIII chega, para Grundmann, em 1311-12, quando, "assim como as políticas de Inocêncio III haviam forçado o movimento da pobreza e dos pregadores itinerantes a decidir ou a se integrarem às ordens da Igreja ou a serem perseguidos como heréticos" forçaram-se "grupos de beguinos e beguinas a tomarem uma posição final quanto a se eles queri- 
am abandonar seu movimento livre, não-regulado (freien, ungeregelten Bewegung), e adotar um modo de vida estável e ordenado (beständigen, geordneten Lebensformen), submetendo-se às regras da Igreja. Essa questão não dizia respeito apenas às formas organizacionais (Organisationsformen), mas decidiria se o pensamento religioso e a especulação mística (das religiöse Denken und die mystische Spekulation) seriam restringidos pelas normas teológicas (theologischen Normen) da ortodoxia eclesiástica" $(R B, 437)$.

Grundmann chega assim ao capítulo 8, o último do livro, em que examina "as origens de uma literatura religiosa em vernáculo", da qual nasceria o "Misticismo Alemão" no começo do século XIV. Esse processo é, segundo Grundmann, resultado do surgimento de um novo estrato entre laicos e clérigos, que, como os primeiros, não liam ou escreviam em latim, mas, como os segundos, queriam ler e escrever escritos religiosos. Ele é resultado do movimento religioso em direção à adoção de uma forma, em seu contato com a Igreja: "onde quer que homens com formação teológica participassem do movimento religioso das mulheres, o solo estava preparado para uma literatura religiosa em vernáculo" $(R B, 457)$. É, portanto, o signo positivo do "movimento" religioso de que trata Grundmann ao longo do livro, o movimento em direção à forma religiosa, forma organizacional que é também uma objetivação da experiência religiosa em escritos elaborados, em experiência ou pensamento objetivado em forma literária. ${ }^{78} \mathrm{~A}$ multiplicidade das formas que resultam da objetivação do subjetivo, apesar de não serem sistematicamente tratadas ou diferenciadas por Grundmann, que se ocupa sobretudo da institucionalização em termos de ordens religiosas, está prevista no sistema de Freyer, para quem, "como derivação da atividade espontânea da vida, o espírito objetivo adota diferentes formas segundo o modo como se efetua a atividade, isto é, segundo a maneira pela qual a espontaneidade se objetiva e se fixa."79

Fica claro, assim, que, apesar de não se deter na teorização de seu objeto, o livro de Grundmann tem um fio-condutor seguro, identificado desde sua epígrafe e perseguido consistentemente ao longo da obra. Grundmann delimita seu objeto e constrói sua narrativa no descompasso entre o subjetivo e o objetivo, entre o impulso religioso e sua realização como forma. Entre um e outro, existe um espaço de que ele se faz historiador, um "movimento" que parte da subjetividade - e é movido por ela - em direção à objetivação. Em consonância com a revisão do historismo, Grundmann se faz historiador de um objeto que é, por excelência, um vir-a-ser. Objeto que é uma ontogênese histórica que desemboca, ademais, pela multiplicidade de seu acontecer, em

\footnotetext{
${ }^{78}$ É fundamental o papel dessa heresia no conjunto da argumentação de Grundmann, na medida em que é ela que se opõe à objetivação do movimento religioso. Aqui parece que as próprias posições de Grundmann ficam mais claras: "Na realidade, aqui se encontram as fontes de perigo para o movimento religioso feminino: acreditar que o seu próprio espírito e o espírito dos outros fossem o espírito de Deus, e levar as experiências religiosas a uma espiral para o sem-limite - o movimento religioso das mulheres estava sujeito a essa tentação onde ele não fosse mantido em caminhos seguros pela estrita disciplina e regra, e assim surgiu aquele 'espírito de liberdade', primeiramente visto nas comunidades femininas no Sul da Alemanha, que eclodiu abertamente pela primeira vez em heresia no Ries suábio e que, no fim do século, tinha impregnado e posto em perigo todo o movimento religioso" $(R B, 402)$. ${ }^{79}$ MORA, José Ferrater. Dicionário de Filosofia: tomo II, E-J (1994). São Paulo: Loyola, 2001, p. 1152.
} 
uma verdadeira ontologia histórica. Tendo esboçado a distinção entre dois planos ontológicos e investigado a dinâmica processual entre eles, resta-nos, agora, penetrar no sentido do "religioso", análise que nos permite cernir de maneira mais clara o sentido do plano ontológico que assume preeminência processual e aprofundar, destarte, o problema da processualidade em Movimentos religiosos na Idade Média.

\section{b) A Especificidade do Religioso}

Na introdução do livro, Grundmann delimita claramente um espaço de autonomia do "religioso":

Desde o fim do século XIX, houve muitas tentativas de se conceber os movimentos religiosos da Idade Média como um processo histórico geral (als einen geschichtlichen Gesamtvorgang). Mas, nessas tentativas, o interesse pelo significado social e econômico desses movimentos esteve tão fortemente em primeiro plano, que seu sentido e conteúdo religioso (ihren religiösen Sinn und Gehalt) foram praticamente ignorados, ou distorcidos como meros subterfúgios da época para encobrir motivos e objetivos genuínos, sociais. $(R B, 8)$

Diferentemente dos que critica e em consonância com a viragem para o subjetivo que caracteriza o esforço das Geisteswissenschaften, as investigações de Grundmann "tentarão compreender a peculiaridade original, as forças históricas e os objetivos religiosos desses movimentos (die ursprüngliche Eigenart, die geschichtlichen Kräfte und die religiösen Ziele jener Bewegungen)" (RB, 8). A retórica não deixa de lembrar o trabalho de Huizinga, na contraposição a uma explicação tradicional de base objetivista, que se quer revisar pela consideração do subjetivo como imanência criadora. Referindo-se às idéias da pobreza cristã e da vida apostólica, Grundmann diz:

Nenhuma observação imparcial pode duvidar de sua convicção genuína e apaixonada de terem renovado e realizado a verdadeira Cristandade evangélica e apostólica em suas vidas; eles demonstraram muito freqüentemente que sua prontidão em sofrer o martírio por essas convicções não era apenas uma forma de falar vazia. Levar a sério essas convicções e alegações é a primeira condição para se entender os movimentos religiosos da Idade Média. $(R B, 22-23)$

Isto é, é necessário colocar-se na posição de compreensão da subjetividade dos agentes. Uma vez que os movimentos religiosos têm uma motivação auto-centrada, religiosa, fica estabelecida uma lógica própria (Eigengesetzlichkeit) a esse domínio. Como fica evidente, essa lógica é da ordem da subjetividade ("objetivos", "convicção"). Em termos sucintos, o religioso é o plano por excelência do subjetivo imanente. 
É com esse propósito de demarcar a esfera do religioso como respondendo a uma lógica própria, que, referindo-se a um herético, Grundmann afirma: "Nesse caso, um tecelão não se transformou em um herético, mas um herético se transformou em tecelão" $(R B, 33)$. No mesmo espírito, mostrando que, diferentemente do que outros haviam pensado, os que aderiram ao movimento religioso não eram prioritariamente membros das classes inferiores, Grundmann questiona a idéia de que a aderência ao movimento tenha se dado por razões econômicas:

Bernardo de Claraval já afirmou - e isso tem sido muito repetido desde então - que os grupos superiores e a nobreza em particular promoveram e protegeram a doutrina herética da pobreza religiosa por motivos econômicos e políticos profanos, por ganância, um desejo de dinheiro e terras, não por razões religiosas (religiösen... Motiven), para se enriquecer às custas dos bens da Igreja. Tais motivos efetivamente podem ter falado alto a muitos dos senhores politicamente interessados da Provença, mas de modo algum eles poderiam ter levado à participação de quase toda a nobreza, à firme relação das mulheres nobres aos pregadores heréticos, e à conversão de muitos nobres ricos em pregadores vagantes voluntariamente pobres. As idéias e estímulos religiosos foram sempre decisivos,... $(R B, 38$, grifos nossos).

É nesse contexto que podemos entender melhor a função do capítulo 3, "A origem social dos humiliati, valdenses e franciscanos", a que havíamos prometido retornar. Grundmann está aqui preocupado em desfazer o mal-entendido de que "o movimento de pobreza religiosa nasceu das mais baixas camadas sociais,..., que ele teria sido, portanto, um 'movimento social' nascido de uma necessidade econômica e dirigido contra os grupos superiores" $(R B, 157)$. Grundmann se opõe às interpretações que "querem entender os movimentos espirituais e religiosos como epifenômenos de processos sociais e econômicos (die geistigen und religiösen Bewegungen als Folgeerscheinungen sozialer und wirtschaftlich Vorgänge)" (RB, 158). Sua conclusão sobre os franciscanos, que estende aos demais, é a de que, se é possível achar qualquer denominador comum para as origens sociais, ele "deve ser que membros de todos os grupos e camadas entraram na ordem sem distinção, mas tomaram parte, sobretudo, a rica burguesia, a nobreza e o clero - não as camadas dos pobres artesãos, nem do proletariado industrial" $(R B, 167) .{ }^{80}$ Separando a esfera religiosa como um domínio autônomo, Grundmann não exclui que ela possa funcionar de maneira reativa (como quando a-

\footnotetext{
${ }^{80}$ Uma tônica de autonomização explícita do religioso por meio do questionamento das origens sociais dos participantes do movimento religioso perpassa o conjunto do livro. Por exemplo, ao falar do movimento feminino: "Tanto quanto as relações sociais das mulheres religiosas no tempo das primeiras beguinas podem ser determinadas, não pode haver dúvida de que não era a falta de meios, mas antes a fuga das riquezas que determinou sua decisão pela pobreza voluntária, e que lhes faltava não o acesso ao casamento, mas o desejo de casar" $(R B, 189)$.
} 
firma que "ele [o movimento] não é uma reação dos deserdados, dos empobrecidos, dos excluídos contra as camadas dirigentes na Igreja, na sociedade e na cultura de seu tempo, mas antes uma reação religiosa (eine religiöse Reaktion), no círculo dessas camadas dirigentes, contra o desenvolvimento social, econômico e cultural", $R B, 168$ ), mas ela parte de um impulso próprio ao campo religioso, entendido como campo de uma subjetividade autônoma e, portanto, imanente. ${ }^{81}$

Para Wolfgang Schöpf, é nas próprias convicções religiosas de Grundmann que se encontraria a motivação profunda dessa posição: "Apenas a delimitação de objetivos religiosos e reformadores era a característica definidora. A institucionalização e a canalização por meio da hierarquia da Igreja do século XIII permaneceu distante durante toda a vida de Grundmann e lhe pareceu - bem de acordo com sua visão de mundo protestante (pietista) - uma excessiva redução da ação do espírito de Deus." 82 Seja qual for a motivação profunda dessa posição, importa marcar que ela é consistente ao longo da obra de Grundmann, inclusive nos trabalhos posteriores, a despeito de um interesse mais marcado pelas instituições na segunda fase de sua carreira. É assim que a questão central de sua História da heresia na Idade Média é definida como o problema de um embate entre heresia e Igreja "em torno da verdadeira compreensão e da correta observância e realização do cristianismo." ${ }^{83}$ No caso específico da pataria, no século XI, não se tratava de "uma reforma social ou política, mas religiosa e eclesiástica, de uma subversão do estado das coisas, mas de uma purificação da Igreja." 84 No caso das universidades, explica Grundmann:

A origem e a base de existência das universidades repousam não na urgência geral de formação ou em uma necessidade de educação para o trabalho, nem em interesses políticos, eclesiásticos, econômicos ou sociais,

\footnotetext{
${ }^{81} \mathrm{O}$ ponto de partida histórico dessa autonomização pode ser traçado a partir do Iluminismo. Em um artigo que questiona a noção de história religiosa, Jean-Claude Schmitt afirma: "Nosso conceito de religião é recente. Grosso modo, ele data da época das Luzes, do momento em que o cristianismo, minado em seu estatuto de ideologia toda-poderosa, se tornou objeto de uma reflexão crítica e desmistificadora. A 'religião' foi concebida como uma esfera autônoma e o resultado de uma livre escolha da consciência individual. Essa mutação cultural de primeira importância não pode ser separada do conjunto das mudanças sociais e políticas que marcam o fim do Antigo Regime" ("Une histoire religieuse du Moyen Age, est-elle possible?". In: SCHMITT, Jean-Claude. Le corps, les rites les rêves, le temps: essais d'anthropologie médiévale. Paris: Gallimard, 2001, p. 31-41, aqui p. 32. Jean-Claude Schmitt já havia se oposto ao uso do termo em texto anterior, respondendo ao artigo de van Engen que mencionamos mais atrás. O historiador indica como o uso do termo desde o século XIX esteve relacionado à oposição entre a vida privada e o poder público do Estado laico. "Disso deriva o desequilíbrio que aparece nessa era na noção de religião que privilegiava apenas o conteúdo: crença e fé acima de ritos coletivos" JeanClaude SCHMITT. "Religion, Folklore, and Society in the Medieval West". In: LITTLE, Lester K. e ROSENWEIN, Barbara H. (Ed.). Debating the Middle Ages: issues and readings. Nova Iorque: Blackwell, 1998, p. 376-387, aqui p. 384 .

82 Wolfgang G. Schöpf, “Herbert Grundmann”, op. cit..

${ }^{83}$ GRUNDMANN, Herbert. Ketzergeschichte des Mittelalters, op. cit.. p. 2.

${ }^{84}$ Idem, ibidem, p. 14.
} 
embora eles mais tarde tenham tentado influenciar a universidade ou tomar posse dela, mas antes na vontade espontânea de conhecimento e saber (in spontanen Wissen- und Erkennen-Wollen). ${ }^{85}$

É claro que aqui entramos no domínio próprio da causalidade, uma noção problematizada por Grundmann já em seu estudo sobre Joaquim de Fiore, em que afirma que "a história espiritual não pode ousar reconstruir uma cadeia causal sem buracos; mas ela pode correlacionar aquilo que é afim do ponto de vista das idéias e pode separá-lo das outras idéias e tendências." ${ }^{86}$

Demonstrar a imanência do campo subjetivo e como ele produz, como transcendência, o mundo objetivo é nexo central que articula o conjunto da empresa historiográfica de Grundmann, especialmente nos anos em torno de Movimentos religiosos na Idade Média. Contra os investigadores que pensam "em termos sociológicos e históricos", para entender os movimentos espirituais, deve-se perguntar: "onde encontramos as fontes espirituais? não assistimos no passado, em algum lugar, à criação dessas idéias no reino do pensamento?" ${ }^{87}$ Contra os historiadores que não dão atenção à visão medieval da história, Grundmann sentencia:

Mesmo se não tomamos as visões da Idade Média a respeito da história por verdadeiras e corretas, também precisamos perguntar até que ponto elas foram ativas (wieweit sie wirksam waren) e, como resultado disso, elas são importantes para a compreensão dos pressupostos espirituais, das forças propulsoras e das idéias mestras da história e da política medievais. $^{88}$

A crermos nos termos dos Estudos sobre Joaquim de Fiore, onde Grundmann é mais explícito e onde faz mais apartes teóricos, o locus do religioso é a consciência individual - configurando, assim, um claro subjetivismo idealista:

Hoje nós podemos entender de qual movimento global de caráter psíquico-espiritual dão testemunho esses fragmentos de uma viragem espiritual (...) podemos compreendê-lo melhor do que os juízes medievais (e modernos) dos heréticos, que buscavam seus motivos sempre na depravação moral. ${ }^{9}$

\footnotetext{
${ }^{85}$ GRUNDMANN, Herbert. Vom Ursprung der Universität im Mittelalter. Darmstadt: Wissenschaftliche Buchgesellschaft, 1960, p. 58.

${ }^{86}$ GRUNDMANN, Herbert. Studi su Gioacchino da Fiore, op. cit. p. 173.

${ }^{87}$ Idem, ibidem, p. 5.

${ }^{88}$ GRUNDMANN, Herbert. "Die Grundzüge der mittelalterlichen Geschichtsanschauungen". Archiv für Kulturgeschichte, 24, 1934, p. 326-336, p. 327.

${ }^{89}$ GRUNDMANN, Herbert. Studi su Gioacchino de Fiore, op. cit., p. 14.
} 
Evidentemente, por detrás dessa perspectiva, encontramos um plano de subjetividade universal, que se opõe ao sujeito histórico diltheyano. Com efeito, ao comentar a visão histórica de Joaquim de Fiore, Grundmann afirma:

A identificação dos conceitos "temporal", "terreno", "transição", "imperfeito" não é uma posição arbitrária da Idade Média cristã e não é apenas um acessório de sua herança recebida da Antigüidade. Trata-se antes de uma visão que é sempre conforme a uma atitude típica do espírito, para o qual o valor, a verdade, o espírito, o divino são sempre atemporais e transcendentes, sem se modificar, sem passar, sem história, e todo acontecimento na Terra é apenas queda do espírito, perda do ser puro e verdadeiro, pecado original e sua reparação..$^{90}$

Aqui também Grundmann está próximo de Goetz. Assim, se Goetz identifica o "novo idealismo cristão" como um fenômeno histórico dos séculos XII-XIII, ele abre a possibilidade, na descrição do ideal de Francisco, para se conceber esse novo idealismo cristão como uma tomada de consciência para um conteúdo que já está lá antes da conscientização: "ele não quer formar algo de novo a partir da própria alma (Neues aus der eigenen Seele gestalten), mas antes despertar a alma individual para um conteúdo que já está dado (einen bereits vorhandenen Inhalt)." 91

Cerca de quinze anos antes de Movimentos religiosos na Idade Média, em seu curso de 1920-21 em Friburgo, que intitulou "Introdução à fenomenologia da religião", Martin Heidegger (1889-1976) passou em revista a orientação das pesquisas de Ernst Troeltsch (1865-1923) sobre a religião, considerando-o "o representante da filosofia religiosa atual de maior destaque." 92 Heidegger identifica diversos problemas na filosofia religiosa de Troeltsch, notadamente a busca de uma definição transcendental da religião e a distinção entre "fenômeno principal" (a fé) e "formas periféricas" (a sociologia e a ética econômica), com passagem do primeiro às segundas. Para Troeltsch, na leitura de Heidegger, "a história da religião considera a realização do a priori religioso no curso fático da história do espírito." 93 A religião como a priori é, para Heidegger, um objeto criado pela e para a ciência, e não algo que se produz naquilo que denomina a experiência fática da vida, campo de uma ontologia da historicidade. Referindo-se, nesse campo de problemática, à noção de objeto, Heidegger afirma:

\footnotetext{
${ }^{90}$ Ibidem.

${ }^{91}$ GOETZ, Walter. "Franz von Assisi und die Entwicklung der mittelalterlichen Religiosität", op. cit., p. 182.

${ }_{92}$ HEIDEGGER, Martin. Fenomenologia da vida religiosa. Petrópolis/Bragança Paulista: Ed. Universitária São Francisco/Vozes, 2010, p. 23.

${ }^{93}$ Idem,p. 26.
} 
Histórico diz aqui: tornar-se, surgir, ocorrer no tempo: uma caracterização que vai ao encontro de uma realidade. Na medida em que se permanece na consideração do conhecimento da relação objetiva, cada caracterização ou mudança do sentido do "histórico" é sempre determinada através desse conceito prévio de objeto. O objeto é histórico; ele tem a propriedade de ocorrer no tempo, de transformar-se. (...) O histórico é vitalidade imediata. ${ }^{94}$

Nas anotações para o curso "Os fundamentos filosóficos da mística medieval" (1918-19), que não chegou a dispensar, na introdução à seção sobre a irracionalidade em Mestre Eckhart - figura conhecida de Grundmann - Heidegger dá a entender como concebe essa noção de vitalidade que evita o a priori do religioso:

A imediaticidade da vivência religiosa, a vitalidade irrestrita e exposta da entrega ao sagrado, ao divino, não extrai de si mesma a forma - nem a reflexão ao caráter genuíno do desempenho - mas se dá como culminação de uma determinada teoria do conhecimento e psicologia historicamente condicionadas, culminação que por sua vez gera, como tal, precisamente o novo e o correlato da vitalidade vivencial. ${ }^{95}$

Ora, se Grundmann se ocupa de um vir-a-ser, trata-se do movimento de objetivação do religioso, mas o religioso em si não é temporalizado como um vir-a-ser, sendo antes arrancado da historicidade como um a priori do espírito. Assim, em larga medida, a crítica heideggeriana pode se aplicar a Grundmann avant la lettre.

Em resumo, Grundmann examina os movimentos religiosos, entendidos como desenvolvimentos ou desdobramentos coletivos da subjetividade religiosa (a religião para ele é uma realidade subjetiva imanente) em direção à sua objetivação em formas. Entre os dois planos ontológicos que constroem a narrativa, um é mais bem delimitado (o religioso, pólo subjetivo imanente), enquanto o outro fica em parte em aberto, por ser apenas um télos narrativo (o plano transcendente, que é o pólo objetivo). Nesse construto, que consagra a imanência da subjetividade como fator de uma processualidade histórica, configura-se uma narrativa historiográfica cuja temporalidade essencial é a da inscrição do tempo na ontologia do objeto, o vir-a-ser da forma a partir de um movimento impulsionado pela subjetividade que, em si, é.

\section{Conclusão}

Nesta breve conclusão, cabe agora apenas a tarefa de sucintamente cotejar as respostas dadas por Huizinga e por Grundmann diante do panorama de crise do his-

\footnotetext{
${ }^{94}$ Idem, p. 33, grifos do autor.

95 Idem, p. 300.
}

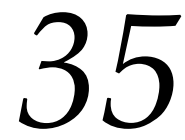


torismo objetivista. Usando a imagem de que Grundmann se valeu para falar da relação entre inquisidor e heresiarca, em um brilhante artigo metodológico, poderíamos dizer que os dois historiadores eram "parceiros em um mundo espiritual que os envolvia a ambos." ${ }^{96}$ Ancorando-se em uma tradição longa de conceitualização da noção de forma, centrada na releitura do conceito hegeliano de "espírito objetivo", os dois sabem que apenas podem partir dos trajes de brocado com que a história se dá a ver. Porém, para ambos, esses trajes são indícios de um conteúdo (o espírito, Geist) que o produziu. Huizinga e Grundmann partem, assim, de uma ancoragem objetiva para investigar o processo que deu origem a essa instância objetiva. Eles compartilham, destarte, de uma mesma processualidade de base, que enfatiza uma determinação subjetiva de fundo.

Porém, essa processualidade está inserida em quadros teóricos diversos para um e outro autor, de modo a configurar duas vias opostas para a práxis historiográfica. Grundmann configura uma espécie de processualidade fechada, em que a processualidade de base, formada por dois planos ontológicos concatenados unidirecionalmente, é o nexo explicativo essencial. O resultado é uma historicidade parcial, em que o tempo existe apenas na produção do objetivo (que é domínio exclusivamente transcendente) pelo subjetivo (que é domínio exclusivo da imanência), deixando um largo espaço trans- ou a-histórico na compreensão do que configura o objeto do historiador. Já Huizinga constrói, em última instância, uma processualidade dialética, pois, mesmo distinguindo entre imanência e transcendência, ele identifica uma força da transcendência constituída que influi na imanência, resultando em uma historicidade profunda que envolve o movimento de todos os planos ontológicos, que são, para ele, pelo menos quatro, e não apenas dois. É uma perspectiva que atende ao chamado heideggeriano, para quem "a tendência da compreensão fenomenológica [leia-se filosófica, dada a sinonímia determinada por Heidegger nesta obra] é fazer a experiência da objetualidade em sua originariedade." ${ }^{97}$

Nesse sentido, pode-se dizer que a historiografia de Huizinga é mais radical, desvestida da perspectiva do sujeito transcendental kantiano e mais afim aos pontos de vista de Dilthey e de Heidegger, enquanto Grundmann está mais ancorado na existência de um sujeito transcendental e nisso se aproxima mais da posição dos neokantianos de Baden, mas ele verte as preocupações partilhadas no campo próprio da prática historiográfica. É bastante sintomático que a historiografia tenha, desde então, optado por discutir mais a via radical e seguir a moderada. Talvez isso se deva ao fato de que, como, para Huizinga, em seus próprios termos, "o mundo conceitual do historiador é demasiado fluido, e suas conclusões são demasiado soltas", ${ }^{98}$ falte um senso de ancoragem firme no real e de certeza dos caminhos trilhados que é, no entanto, caro aos historiadores. Talvez estejamos aqui diante de uma aporia fundamental da his-

\footnotetext{
96 GRUNDMANN, Herbert. "Ketzerverhöre des Spätmittelalters als quellenkritisches Problem". Deutsches Archiv für die Erforschung des Mittelalters, 21, 1965, p. 519-575, aqui p. 559.

${ }^{97}$ HEIDEGGER, Martin. Fenomenologia da vida religiosa, op. cit. p. 69.

${ }^{98}$ HUIZINGA, Huizinga. "The task of cultural history", op. cit. p. 18.
} 
toriografia contemporânea, ainda atormentada pelo fantasma da prova para além da retórica. ${ }^{99}$ Torna-se urgente assim, para uma última vez recorrer a termos de Heidegger, um mergulho nesse debate, mergulho que torne o mundo circundante dessa problemática um mundo compartilhado com o nosso próprio.

\footnotetext{
${ }^{99}$ Para uma visão a respeito desse problema, ver GINZBURG, Carlo. Relações de força. História, retórica, prova. São Paulo: Companhia das Letras, 2002.
} 